\title{
Juan Sin Tierra, rey de Inglaterra, en el cine
}

\author{
John Lackland, King of England, at the Movies
Francisco Saulo Rodríguez Lajusticia
Universidad de Cantabria
https://orcid.org/0000-0002-9194-8360
rodriguezfs@unican.es

Recibido: 17/04/2020; Revisado: 03/09/2020; Aceptado: 22/10/2020

\begin{abstract}
Resumen
Juan Sin Tierra se ha convertido en uno de los reyes medievales ingleses más conocidos por el gran público. El cine ha ido variando su imagen, presentándolo a veces como el peor villano imaginable capaz de todo tipo de crueldades y otras como alguien torpe, inseguro y lleno de traumas. Juan Sin Tierra ha sido utilizado también para personificar valores propios del siglo XX y se ha cargado de connotaciones negativas. El objetivo es mostrar la visión que el cine ha ofrecido de él y ofrecer el contraste con la realidad de alguien no más cruel que sus contemporáneos.
\end{abstract}

Palabras clave: Juan Sin Tierra; Ricardo Corazón de León; Inglaterra; cine; Robin Hood.

\begin{abstract}
John Lackland has become one of the most famous English medieval kings. The cinema has continuously changed his image, presenting him sometimes as the worst human being imaginable, capable of all kinds of cruel behaviours, and sometimes as clumsy, insecure and beset by various traumas. John Lackland has also been used to epitomize the values of the twentieth century and burdened by negative connotations without documentary evidence. The objective of this work is to demonstrate his cinematic portrayal and to offer the contrasting reality of someone no more wicked than his contemporaries.
\end{abstract}

Key words: John Lackland; Richard the Lionheart; England; cinema; Robin Hood. 


\section{INTRODUCCIÓN}

Juan I de Inglaterra (1166-1216), más conocido como Juan Sin Tierra, es uno de los monarcas medievales más fascinantes cuya figura ha sido constantemente vilipendiada hasta el hecho de haberse convertido en uno de los villanos por excelencia de nuestra infancia o, por lo menos, de las de todos los que crecimos rodeados de cuentos como el de Robin Hood. Protagonista en no pocas historias, el cine ha producido películas desde su mismo nacimiento a finales del siglo XIX en las que se ha proyectado una imagen de Juan Sin Tierra que, en la inmensa mayoría de las ocasiones, nada o muy poco parece tener que ver con la realidad, habiéndose enormemente magnificado los vicios que se le atribuyen, cuando no fueron completamente inventados para ajustarse a las mentalidades imperantes en los diferentes momentos del siglo xx en los que se rodaron las películas.

Aunque no cabe duda de que el cine es, fundamentalmente, entretenimiento y, por lo tanto, ficción que no necesariamente está obligada a recoger la realidad, es el medio junto a la televisión que más llega a una sociedad caracterizada por, en términos generales, una mayor cantidad de espectadores que de lectores. Es por ello por lo que cualquier película de cualquier género tiene por lo general un mayor alcance que cualquier escrito. Es una realidad a la que los historiadores no podemos dar la espalda y que ya advertía RosenstONE (1997: 29) a finales del siglo pasado:

Hoy en día la principal fuente de conocimiento histórico para la mayoría de la población es el medio audiovisual, un mundo libre casi por completo del control de quienes hemos dedicado nuestra vida a la historia. $\mathrm{Y}$ todas las previsiones indican que esta tendencia continuará. No hace falta ser un adivino para asegurar que llegará un día (¿no estamos muy cerca?) en el que escribir historia será una especie de ocupación esotérica y los historiadores unos comentaristas de textos sagrados, unos sacerdotes de una misteriosa religión sin interés para la mayoría de las personas que -esperemos- serán lo bastante indulgentes como para seguir pagándonos.

Considerando la sustancial cantidad de estudios que centran su mirada en el cine y en cómo este ha ido reflejando nuestro pasado, algunos de los cuales citaré en el siguiente apartado, el objetivo de este artículo es acercarnos al recorrido biográfico que el séptimo arte ha realizado acerca de un monarca retratado a menudo como un gran villano y que, cuando se viaja al Reino Unido hoy en día, parece incluso que no hubiera existido.

\section{PUNTO DE PARTIDA Y METODOLOGÍA}

Se hace necesario reflexionar sobre una cuestión fundamental antes de continuar y que es si el cine puede considerarse un instrumento válido para aproximarse al pasado y cómo lo han considerado los historiadores. La actitud en general de estos con respecto a la literatura, al séptimo arte y a la capacidad de ambos para reflejar el pasado es bastante diversa y van desde un Jacques LE Goff (2008: 13) que confesaba haberse iniciado en los estudios de la Edad Media «merced a la lectura de Walter Scott (y en concreto Ivanhoe, publicado en 1819)» hasta un Ramón Teja (1999: 89) que afirmaba que «cuando en mi condición de historiador de la antigua Roma comencé hace años a ocuparme de la historia de 
los orígenes del cristianismo tuve que llevar a cabo un enorme esfuerzo intelectual para ir liberándome paulatinamente de los mensajes que desde mi juventud habían ido dejando en mi mental imaginario las llamadas películas de romanos».

Aunque hace ya casi medio siglo Marc FERro (1980: 20) denunciaba que «poco falta para que el cine ya sea centenario, pero aún se ve relegado a la ignorancia y ni siquiera figura entre aquellas fuentes de las que hoy se prescinde. No entra para nada en el universo mental del historiador», lo cierto es que muchos se mantuvieron reacios a admitir la validez de los mensajes que transmite como si el mero hecho de ser historiador implicara necesariamente negarlo o, cuando menos, cuestionarlo. Son especialmente significativas unas palabras de Guillermo FATÁs (1999: 66) comentando Espartaco (Stanley Kubrick, 1960) ${ }^{1}$ y afirmando ser admirador de este director «aunque haya de justificar mi presencia a base de pequeñas censuras de detalle», expresando este autor, a mi modo de ver, cierta incomodidad por la obligación que parecemos tener los historiadores de ser críticos con lo que se aleja de los métodos que hemos aprendido y, en su caso concreto, por tener que proceder en su intervención a señalar los errores históricos que contiene la película de Kubrick aunque a su vez considere que eso es lo de menos.

En el otro extremo, otros autores han señalado no solo la plena validez del cine para hacernos sentir todo aquello que no puede transmitir el documento escrito como el «color, el sonido, el movimiento, los escenarios, las texturas y las emociones» (ROSENSTONE, 2014: 27), sino que incluso han justificado las alteraciones de la realidad porque «la historia de los historiadores no se puede presentar en las pantallas sin adecuaciones. Porque la explicación racional exacta y meticulosa mata la esencia del cine, el drama y, además, no es lo que busca el espectador, normalmente interesado en lo que pasó» (MONTERo, 2008: 138).

Muy conocida y repetida es la idea expresada por Aristóteles de que la virtud se encuentra en un punto medio. Creo que en esta compleja relación entre historia y cine se hace necesario alejarse de las posturas extremas. Seguir negando el enorme potencial que tiene lo audiovisual y considerar por consiguiente que solo lo que nos transmiten las fuentes escritas es lo válido para acercarse al pasado o para transmitir cómo era ese pasado supone en mi opinión quedarse anclado en viejos planteamientos y ponerse una venda en los ojos ante un mundo muy diferente al que existía en el siglo xx. Admitir por el otro lado cualquier adulteración en beneficio de la obra cinematográfica simplemente para que le resulte más atractiva al gran público y, en definitiva, para que obtenga una mayor cantidad de beneficios económicos me resulta una postura legítima si hablamos de entretenimiento, pero cuestionable si un largometraje sí que pretende convertirse en un referente sobre un tema, personaje, batalla...y más cuando así lo publicita o lo pretende vender.

En el caso de la Edad Media, se trata de un periodo lleno de estereotipos negativos $\mathrm{y}$, por lo general, bastante mal conocido. Mi coincidencia con Juan Vicente GARCíA (2015: 136) es absoluta cuando este afirmaba que

1 Las películas que fueron estrenadas en España figuran en este artículo con su título en español, mientras que las que no lo fueron constan con el original. Este detalle se ha comprobado consultando (AgUILAR, 2018), quien también adopta este mismo criterio. 
$\mathrm{Si}$, por otra parte, tenemos en cuenta que los nuevos planes de estudio para Secundaria y Bachiller han dejado en muchas comunidades autónomas que lo poco que los alumnos se considera que deben conocer sobre la Edad Media se concentre en $2^{\circ}$ curso de la ESO, es decir, cuando cuentan apenas 13 o 14 años, de manera que la mayoría de ellos nunca más volverán a oír hablar en un aula sobre ese período, es evidente que su visión de la historia que transcurre entre los siglos v y xv proviene de otras fuentes y no precisamente de las académicas.

En este sentido, considero que los medievalistas nos vemos en la necesidad constante de matizar lo que se ha contado -porque no me refiero únicamente a lo que se ha escrito, sino también a lo que se ha puesto en escena e incluso a lo que se nos ha transmitido oralmente- sobre la Edad Media puesto que se trata probablemente de la época más vilipendiada de nuestro pasado. Si lo audiovisual predomina hoy en día, el historiador no puede quedarse reducido únicamente a lo escrito y, de la misma manera que se realiza un análisis crítico de las fuentes, la obra cinematográfica no debería quedar exenta de dicho análisis cuando esta habla del pasado, si bien esa mirada al cine debe hacerse, bajo mi punto de vista, alejándose de aquellas posturas que niegan su validez con rotundidad como punto de partida inflexible.

Ahora bien, cabe reflexionar sobre qué tipo de películas son aquellas en las que aparece Juan Sin Tierra, puesto que, a excepción de una de 1899 que es prácticamente desconocida a día de hoy, ninguna tuvo a este personaje como protagonista absoluto, por lo que el género biográfico, tan bien descrito por Ángel Luis Hueso y, como él afirmaba, muy en boga durante los años veinte y treinta (Hueso, 2001: 102-103), no nos resulta de utilidad para acercarnos al personaje.

Con la excepción probablemente del Robin Hood de Ridley Scotт (2010), tampoco encontramos al monarca inglés en las grandes superproducciones históricas, de carácter colosal y con miles de extras que la inmensa mayoría de la gente asocia al cine histórico y que tanto explotaría Hollywood a través de directores clave como David W. Griffith o como Cecil B. De Mille.

Nuestra mirada debe centrarse más bien en las películas de época, muy precisamente definidas por José Enrique Monterde, Marta Selva y Anna SolÀ (2001: 138) como aquellas en las que «la Historia pasa de ser el centro a ser el escenario de la intriga» y en las que «lo que aquí interesa son las vicisitudes de una serie de personajes auténticos o inventados, pero posibles, en un marco histórico que con su misma presencia legitima el carácter de ficción histórica mucho más que lo que ocurre durante su transcurso", de manera que "se nos ofrecen predominantemente las tradicionales historias de amor, los dramas familiares, las aventuras con predominio de la acción, etc.».

Es en ellas en las que Juan Sin Tierra emerge, con mayor o menor importancia dentro de la trama en cada una de ellas, aunque habitualmente como un personaje secundario. El método aplicado por lo tanto para la realización de esta investigación ha sido el visionado de las películas más representativas e influyentes para el gran público por la enorme difusión que tuvieron o por el hecho de haberse convertido en grandes clásicos y la elaboración de un recorrido biográfico por la vida del monarca haciendo hincapié, por un lado, en qué conoceríamos de este rey inglés si solo nos fijáramos en lo que nos ha mostrado el cine y, por el otro, contrastando estas visiones con lo que sabemos por otras vías tales como unas fuentes escritas que, como se verá, también están enormemente cargadas de connotaciones 
negativas sobre su figura.

Este artículo se enmarca pues en la línea de aquellos trabajos que, tomando como referencia a un personaje histórico determinado, realizan un recorrido por su filmografía tal y como, por citar tan solo unos ejemplos, han hecho Luis A. García (1999)² o Raquel Aliaga (2014) con Cleopatra o Francesc Marí (2015) en su tesis doctoral sobre Napoleón en el cine.

\section{BREVE ESTADO DE LA CUESTIÓN SOBRE UN POLÉMICO MONARCA}

La fascinación que, de alguna u otra manera, ha despertado Juan Sin Tierra a lo largo del tiempo ha provocado que, en muchas ocasiones, encontremos que se ha utilizado su nombre en diversos productos que nada tienen que ver con él y que, sin embargo, conectan con alguien o algo de lo que todos hemos oído hablar en algún momento de nuestra vida pasada. Quizá los ejemplos más evidentes de esto son la novela de Juan Goytisolo que, publicada en 1975, sería todavía prohibida por la censura de un agonizante franquismo o la serie de cómics Los viajes de Juan Sin Tierra, elaborados por Javier DE IsusI y publicados por la editorial bilbaína Astiberri en la primera década de este siglo XXI (DE IsusI, 2004-2010).

El monarca medieval inglés todavía puede encontrarse hoy en día en no pocas bibliotecas, librerías e incluso en tiendas que venden productos de todo tipo en ediciones destinadas a los niños más pequeños que están aprendiendo a leer y que cuentan las valerosas aventuras de un justiciero que roba a los ricos para dárselo a los pobres en una Inglaterra en la que reina el personaje más malvado que pueda imaginarse, con especial preeminencia de las historias de Robin Hood.

Si primero centramos nuestra mirada en los niños más pequeños, un libro que resume la versión cinematográfica producida por DiSNEY en 1973 -película sobre la que volveré al contener en ella numerosos detalles de interés más allá de los que muestra esta edición- no escatima en recursos que ridiculizan al entonces conde Juan. Al margen de mostrarlo en diversas ocasiones chupándose el dedo por un motivo que no se aclara y que es diferente del que le impulsa a hacerlo en la película, en ropa interior después de haber sido desvalijado, cubierto de barro en una charca o durmiendo rodeado de sacos de dinero, se afirma que «el príncipe Juan metía las manos en los sacos de monedas mientras exclamaba: ¡Me encantan los impuestos! Mi lema es: "Roba a los pobres para dárselo a los ricos" » (DISNEY, 2007: 9). ${ }^{3}$

Si avanzamos en el rango de edad, los niños de entre 6 y 12 años cuentan con un ejemplar de las aventuras de Gerónimo Stilton (2012: 7-8) en el que, sin hacer tantas alusiones a Juan Sin Tierra, sí que, no obstante, se le dedican algunas palabras, especialmente en lo que se refiere a las partes que pretenden contextualizar el mundo en el que se ambienta el libro:

\footnotetext{
2 Aunque el autor se centra en la película de 1963, previamente hace un recorrido por las anteriores Cleopatras del cine, por lo que su trabajo puede considerarse una aproximación al personaje en el séptimo arte que va más allá del análisis de un solo largometraje.

3 No constan en el libro los autores ni dibujantes de esta edición, motivo por el que se cita de esta manera.
} 
A finales del siglo XII reinaba en Inglaterra el buen Ricardo Corazón de León. Cuando subió al trono, su país sufría una terrible penuria: escaseaban la comida, el dinero iy hasta la esperanza! Ricardo decidió partir a las Cruzadas.

De este modo esperaba conquistar tierras y tesoros para proporcionar a sus súbditos un poco de riqueza.

En el momento de partir, confió el trono a su hermano el príncipe Juan, conocido como Juan Sin Tierra. Tan valiente y amado por su pueblo era Ricardo como avaricioso e injusto era Juan, al que sus súbditos aceptaban de mala gana.

Con el tiempo, los abusos de Juan se hicieron cada vez más insoportables: subieron los impuestos, disminuyeron los alimentos y los pobres se volvieron más pobres. ${ }^{4}$

Ingenuo sería pretender que estos libros dirigidos a niños y adolescentes $-\mathrm{y}$, por lo tanto, adaptados a ellos- reflejaran con exactitud los acontecimientos que en ellos se relatan, si bien creo que sí resulta interesante el hecho de que, a diferencia de otros reyes que la sociedad, la historiografía o determinados estándares han considerado crueles, malvados o sanguinarios y que muy pocas personas conocen hoy en día, Juan Sin Tierra sigue presente de alguna manera como uno de los grandes villanos de la época medieval y ese carácter es algo que le queda perfectamente claro a cualquier niño, adulto o anciano que, por ejemplo, tenga entre sus manos un cuento de Robin Hood.

No es nueva, ni mucho menos, esta imagen tan negativa de un rey que no dejó indiferentes a sus súbditos y cuyo descubrimiento de sus restos el 17 de julio de 1797 por parte de unos trabajadores de la catedral de Worcester originó, según Marc MoRris (2015), un considerable revuelo a causa de la multitud que se congregó para observar las labores de exhumación del cuerpo y el desconcierto subsiguiente que llevó incluso al robo de un par de dientes del monarca que no aparecieron hasta que en 1923 se incorporaron al museo de dicha catedral.

Son varios los historiadores que han realizado sendos estados de la cuestión sobre Juan Sin Tierra, haciendo hincapié en las diferentes caracterizaciones que se han hecho sobre el personaje. Creo que el que mejor resume la visión que se ha dado sobre Juan I de Inglaterra a lo largo de los siglos XIX y xx ha sido Graham E. SEEL. Destacando tan solo algunos de los ejemplos que él menciona, J. R. GREEN lo consideró en 1874 el peor de los angevinos, Kate NorGATE habló en 1902 de su maldad casi sobrehumana y James RAMSEY lo caracterizó en 1903 como un tirano cruel y egoísta de la peor clase (SEEL, 2012: 7).

\footnotetext{
$4 \mathrm{Al}$ igual que en el caso anterior, Gerónimo StiLTon no es el autor, puesto que este no es más que un personaje de ficción creado por la escritora italiana Elisabetta Dami. En esta edición se hace constar en su portada a Alejandro Dumas como autor por la versión que él escribió en 1872; sin embargo, es evidente que tampoco se puede considerar a él como el auténtico autor de este libro. Ante esta situación, he optado por seguir la ficha del libro que aparece en el catálogo y en la que se nombra a STILTON como autor.
} 


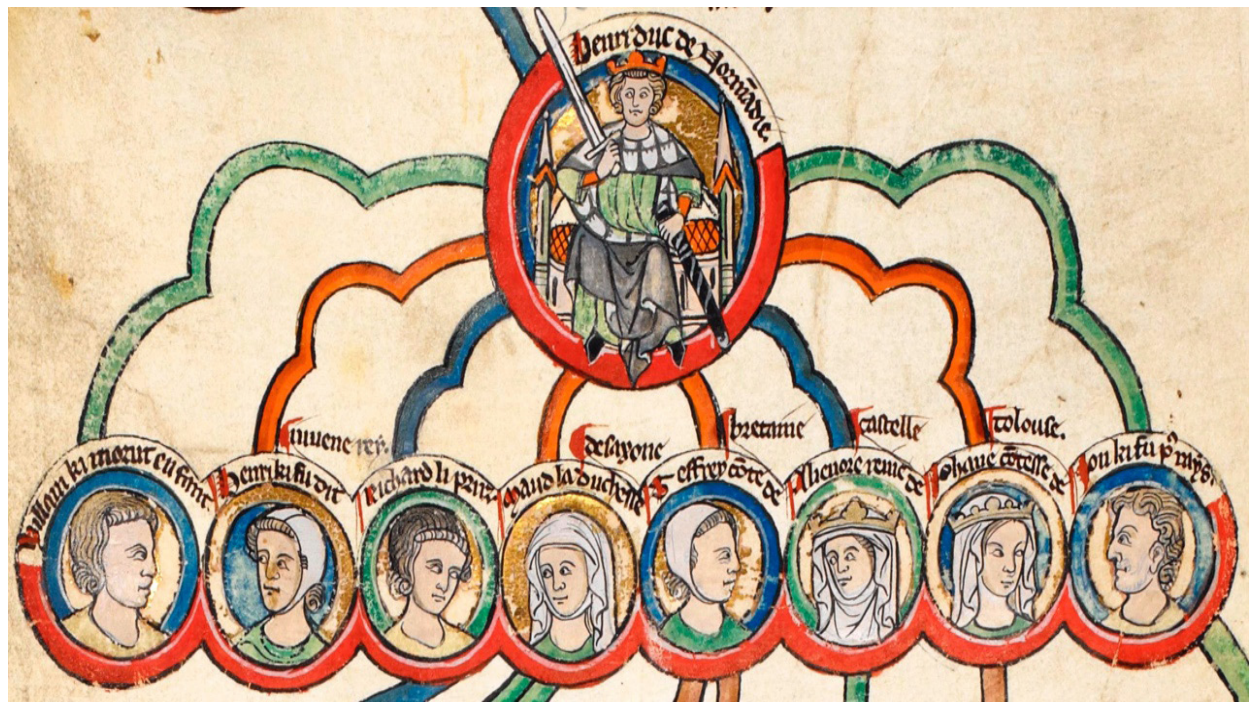

Figura 1. Enrique II y sus descendientes en una genealogía de los reyes de Inglaterra (British Library, Royal 14 B VI). Autor: Anónimo. Dominio público.

Pese a que, tal y como indica el propio SEEL, en los años cuarenta del siglo XX ya hubo especialistas como Vivian Hunter Galbraith que incidieron en los elementos legendarios que tenía la tradicional visión que se tenía de Juan I de Inglaterra y cómo se hacía necesario reevaluar todas estas teorías y replantear de nuevo cómo había sido Juan Sin Tierra (SEEL, 2012: 8), otros maestros de enorme talla como Georges Duby siguieron describiéndolo como el más tenebroso de los personajes que pueda imaginarse, haciendo con ello extremadamente complicado el hecho de combatir, o cuando menos matizar, esta terrible imagen. Así, en palabras de este historiador francés (DuBY, 1988: 42), Juan era

Malquerido, no ha cesado de traicionar y conspirar, primero contra su padre, luego contra su hermano Ricardo Corazón de León (...) Inestable, incapaz de llevar a cabo ningún proyecto militar -por eso se burlaban de su «floja espada»-, mucho más cruel y traidor de lo admitido en un príncipe de su rango, con una sexualidad devastadora -nuevamente la «floja espada»-, Juan Sin Tierra violó permanentemente todas las prohibiciones de la moral cristiana y de la ética caballeresca. Vástago de Melusina, con sangre diabólica en sus venas, se creía que estaba podrido en el interior, poseído, enloquecido por sortilegios y maleficios.

Si especialistas de primera línea como DuBy han optado por seguir describiendo a Juan Sin Tierra de una forma que, en mi opinión, roza el sensacionalismo, no es de extrañar que esta visión, con sus elementos más truculentos, sea la predominante hoy en día cuando consultamos trabajos de divulgación -no por ello mal documentados cuando abordan otros aspectos- como, por ejemplo, el de Eva MiLlet (2018: 54-55) para la revista Historia y vida: 
Entre los estudiosos de la figura de Juan sin Tierra existe el consenso de que, incluso para su época, su crueldad era extrema. Sus acciones -quizá como resultado de esta educación menos castrense- no se regían con arreglo a los códigos de caballería de la época. Mientras que los caballeros preferían capturar al enemigo en vez de matarlo o resolver sus cuitas en justas, Juan optaría por liquidar a sus oponentes con métodos exentos de nobleza alguna. Su favorito era encerrarlos en mazmorras y dejarlos morir de hambre.

Creo que hay un elemento clave que no podemos perder de vista y que ya fue puesto de relieve por Frank MCLYNN (2007: 1) cuando planteó que la historia de Juan Sin Tierra se ha redactado atendiendo a una dicotomía entre el hermano bueno y el hermano malo: «if we judge only by reputation and mithology, Richard I was the greatest king of England in the Middle Ages and his brother John the very worst. The good brother/bad brother dichotomy is a staple of most myths, as old as Cain and Abel». Efectivamente, para muchas personas, historiadores incluidos, Juan era tan malvado porque Ricardo era muy virtuoso y desprovisto de cualquier defecto.

En líneas generales, esta ha sido casi siempre la imagen que de Juan I han transmitido la literatura y el cine, la de un candidato al trono capaz de lo peor con tal de traicionar a su hermano y de hacerse con el poder que este detentaba. Considerando pues que no existe ningún estudio específico sobre Juan I de Inglaterra en la gran pantalla y que se trata de alguien que, lejos de haber pasado de moda, sigue apareciendo hoy en día en series y películas, procederé a hacer un recorrido por las diferentes etapas de su vida atendiendo a sus principales apariciones en la gran pantalla, contrastándolas con los datos históricos que sí tenemos o con las interpretaciones que gozan de mayor credibilidad.

\section{LA ADOLESCENCIA DE JUAN Y EL LEÓN EN INVIERNO (1968)}

No es esta la etapa de la vida de Juan Sin Tierra que más ha atraído a los cineastas, hasta el punto de que podría afirmarse que, de no ser por El león en invierno (Anthony HaRveY, 1968), estaríamos hablando de un periodo no cubierto por nadie. La película ganó tres premios Oscar y fue un completo éxito por reunir un reparto que, entre otros, unía a Peter O'Toole interpretando por segunda vez a Enrique II con una Katharine Hepburn que aquí figura dando vida a Leonor de Aquitania. ${ }^{5}$

Ambientada en Chinon en la Navidad de1183, la película muestra el encuentro entre los reyes -después de que Leonor fuera liberada momentáneamente del encierro al que su marido le había confinado- y sus hijos varones en un tenso momento en el que, apenas medio año después de que hubiera muerto el primogénito, correspondía a Enrique II nombrar a un nuevo sucesor o, cuando menos, despejar el incierto panorama que esto había provocado.

Si tenemos en cuenta que El león en invierno parte de una representación teatral

5 Con respecto a Peter O'Toole interpretando a Enrique II, la primera vez fue en Becket (Peter Glenville, 1964). No hay ninguna aparición del personaje de Juan Sin Tierra en esta película, lo que resulta comprensible puesto que cuando Thomas Becket fue asesinado en diciembre de 1170, Juan todavía no había cumplido los cinco años de edad. 
previa y exceptuamos detalles poco significativos para este estudio como si esto sucedió o no en Chinon o como el hecho de que los regalos al pie de un árbol de Navidad que se ven en una escena no deberían figurar allí por ser una costumbre que no se popularizó hasta el siglo $\mathrm{XIX},{ }^{6}$ lo cierto es que nos encontramos ante una película sobresaliente que muestra a la perfección lo complejo del juego político de la época, con una familia en la que todos los miembros de la misma pactan secretamente entre ellos y están dispuestos a traicionarse a la par que Felipe II de Francia, cuyas tierras estaban invadidas por los angevinos, busca constantemente la desestabilización de todos ellos.

Entre tantos ricos matices y detalles nada inocentes y cargados de intención, destaca sobremanera la imagen que se da de Juan, absolutamente rompedora con respecto a lo que se había visto hasta el momento en el cine. Si antes de esta película nos habíamos encontrado a Juan Sin Tierra como el paradigma de la maldad, en esta ocasión hallamos a alguien completamente diferente, gracias en parte también a la extraordinaria interpretación de un debutante Nigel Terry.

Capacitado para leer en tres idiomas y conocedor de leyes tal y como él argumenta en una escena defendiéndose cuando le consideran inadecuado para el trono, Juan aparece aquí caracterizado como si fuera un niño atrapado en el cuerpo de un adolescente -en la vida real él tenía diecisiete años en este momento-, de extrema inocencia, todavía sin madurar, sin ser capaz de ver las dobles intenciones de sus padres y hermanos y con toda una serie de comportamientos que posiblemente hoy identificaríamos con la hiperactividad y el síndrome de Asperger.

Jugando con el árbol de Navidad mientras sus padres y hermanos confabulan a sus espaldas o entreteniéndose con frenéticas carreras por los pasillos de la fortaleza, Juan aparece retratado como un ser muy manejable, el perfecto peón para los juegos de los demás, a la par que es alguien que provoca repulsión en quienes le rodean, como le sucede a Alais, la amante del rey, que cuando Enrique II intenta convencerla de los beneficios de contraer matrimonio con Juan, replica que tiene granos y huele a estiércol.

6 En cuanto a lo primero, Enrique II estableció su corte en Chinon en la Navidad de 1172 (MARKALE, 1999: 56). Sin embargo, Alex von TunZelmann (2016: 93) señala que «en la vida real, los hechos que cuenta esta película no sucedieron en Chinon durante la Navidad de 1183. La cinta enlaza un encuentro que Enrique tuvo con sus hijos en Angers en un momento anterior de ese año con una cumbre que celebraron Enrique y Felipe II de Francia en Gisors el 6 de diciembre». En cuanto a lo segundo, (Alonso, Mastache y Alonso, 2007: 227). 


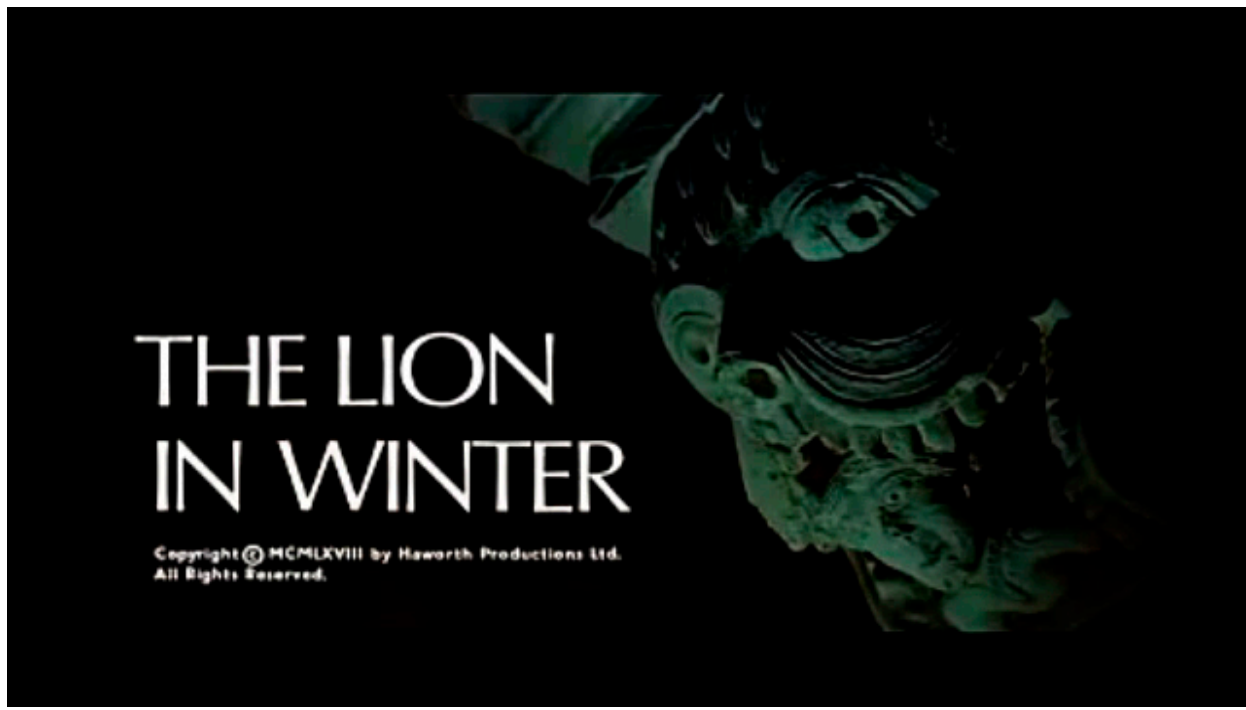

Figura 2. Inicio de los títulos de crédito de El león en invierno (1968). Fuente: Flickr. Autora: Susanlenox. Dominio público.

Un detalle que considero importante de la infancia y adolescencia de Juan es que, en líneas generales, siempre tuvo una muy buena relación con su padre y una muy fría con su madre, la reina Leonor, que mostraba una clara predilección por Ricardo. La coincidencia de la historiografía sobre este hecho es prácticamente total. Tomando como muestra a R. PERnOud (2009: 219),

y la preferencia que Leonor mostró siempre por Ricardo contribuyó al escaso cariño de Enrique por este hijo. Pronto será evidente para todos que la predilección paterna se dirigirá en adelante a su último vástago, Juan, al que había llamado al nacer Juan Sin Tierra, criado lejos de su madre.

El león en invierno muestra a la perfección esta doble relación, con un padre que entrena luchando con su hijo menor nada más comenzar la película o con una madre que anima a Enrique en la parte final de la misma a que clave a Juan un cuchillo en la garganta.

Sería sin duda una excesiva simplificación decir que Juan estaba muy unido a su padre y nada a su madre. Enrique no dudó en utilizar a Juan cuando lo creyó conveniente, especialmente para hacer contrapeso a Ricardo. Por su parte, Leonor tampoco pudo desarrollar un gran apego a unos hijos a los que nunca veía como consecuencia de su casi permanente confinamiento. Con todo, y pese a todos estos matices, creo que El león en invierno es una película desde luego mucho más fidedigna que la inmensa mayoría de las que cubrieron la segunda etapa de la vida de Juan de la que hablaré a continuación y que se corresponde con los años noventa. 


\section{JUAN DURANTE LA AUSENCIA Y EL CAUTIVERIO DE RICARDO CORAZÓN DE LEÓN (1191-1194)}

Sin ningún género de dudas, las películas que abordan esta etapa son las que han hecho famoso a Juan Sin Tierra como un malvado personaje sin escrúpulos que aprovecha la desgracia de su hermano en su propio beneficio para dar rienda suelta a todo tipo de crueldades. Yendo en primer lugar a lo más general, nos encontramos con dos grandes historias a analizar: en primer lugar, las de Robin Hood y, en segundo y con un menor grado de popularidad, las de Ivanhoe, un personaje literario creado en la primera mitad del siglo xIx por Walter SсотT.

\subsection{Las películas de Robin Hood}

Comenzando por Robin Hood, nos encontramos sin duda ante el prototipo de bandido social que ha calado en nuestras conciencias como aquel que robaba a los ricos para dárselo a los pobres, visión esta enormemente parcial que diverge mucho en función de qué versión de sus historias se esté leyendo. Si leemos, por ejemplo, la recopilación de historias sobre Robin Hood que realizó Howard PYLE en 1883 nos encontramos con un personaje que, tal y como se expresa en la contraportada de la edición de 2017, «no es tanto el bandido generoso y rebelde, cuanto un ladrón simpático, astuto, pendenciero y algo fanfarrón, dispuesto a reparar injusticias siempre que ello le reporte diversión y ganancias» (PYLE, 2017).

La fama de Robin Hood como bandido de unas determinadas características, aunque no dejen de ser estereotipadas, ha sido utilizada para caracterizar a otros semejantes de diferentes épocas y partes del globo, como por ejemplo hace HobsBawm (1976: 47 y 49) cuando habla de «Zelim Khan, el Robín de los bosques del Daghestán de principios del siglo XX» o de «Luis Pardo, el Robín de los bosques peruano (1874-1909)».

Lo primero que debemos tener en cuenta antes de avanzar es que, según un completísimo estudio realizado por Miguel AlARCão, las primeras menciones de Robin Hood se contienen en el poema alegórico Pedro el Labrador, escrito por William Langland en torno a 1377, aunque, como advierte el autor, esto no significa que esta fecha fuera realmente la del inicio de su popularidad (AlarCão, 2001: 21). ${ }^{7}$ Esto supone pues que, cuando hablamos de Robin Hood, lo estamos haciendo de alguien cuya primera mención en las fuentes escritas no nos ha llegado hasta doscientos años después y eso tan solo si es que realmente existió alguien así a finales del siglo XII, lo que tampoco parece estar nada claro. ${ }^{8}$

La filmografía de Robin Hood es francamente abrumadora, por lo que solo me centraré en aquellas películas que se convirtieron en las más famosas y que son las que más vio el público o en las que, no cumpliendo esta condición, contengan detalles que, en mi opinión, merezcan ser resaltados. Quedan así

7 El autor señala cómo, hasta 1450 aproximadamente, únicamente podemos hablar de simples menciones de las que tampoco se puede sacar gran información.

8 William E. SimEONE (1953: 307) señala cómo podemos hablar de un Robin Hood que trabajó como sirviente del rey entre diciembre de 1323 y julio de 1324, lo que sitúa al personaje en el reinado de Eduardo II y hace mucho más comprensible que la primera mención llegue en 1377 al no haber transcurrido entonces tanto tiempo como si realmente hubiera vivido en época de Ricardo I. 
mismo descartadas todas aquellas en las que no aparece Juan Sin Tierra, en su inmensa mayoría porque están planteadas solo como un enfrentamiento entre Robin Hood y el sheriff de Nothingham sin que el entonces conde de Mortain tenga cabida en el argumento. ${ }^{9}$

La primera que supuso un gran éxito en la pantalla fue Robin de los bosques (Allan DwAN, 1922), protagonizada por Douglas Fairbanks, uno de los grandes pioneros de la industria cinematográfica al ser uno de los fundadores de la productora United Artists junto a David W. Griffith, Charles Chaplin y su mujer Mary Pickford. Sin duda beneficiada por la enorme popularidad que por aquel entonces gozaba su protagonista, la película se encuentra hoy en día bastante olvidada al haber sido eclipsada por las versiones sonoras que llegaron después.

Si antes aludía a la dicotomía entre hermano bueno y hermano malo de la que hablaba Frank McLYNN, esta se pone de manifiesto al máximo en esta película con un Ricardo jovial, honesto, campechano, generoso y siempre dispuesto a reírse frente a un Juan intrigante, envidioso y de constante rictus serio al que da vida un actor, Sam De Grasse, que más adelante se especializaría en papeles de villano.

Durante la primera media hora la película es un completo desfile de fiesta y alegría, muy en la línea de las que se celebraban en los felices años veinte de la pasada centuria, con multitud de amantes en todos los rincones del castillo y plena diversión por parte de todos, a excepción de dos intrigantes personajes que conspiran a escondidas, Juan y sir Guy de Gisbourne, ${ }^{10}$ deseando alcanzar el poder y llegando a afirmar el primero de ellos que «I'm a Prince».

9 Entre todas las películas en las que no aparece Juan Sin Tierra y que quedan descartadas en este artículo, destacan varias que fueron rodadas entre 1908 y 1913 además de El rey de los bosques (Howard Bretherton, 1948), Tales of Robin Hood (James Tinling, 1951), The men of Sherwood forest (Val Guest, 1954), Sword of Sherwood forest (Terence Fisher, 1960), A challenge for Robin Hood (C.M. Pennington-Richards, 1967), Wolfshead: the legend of Robin Hood (John Hough, 1973) y Robin Hood, principe de los ladrones (Kevin Reynolds, 1991).

10 Se trata de un personaje completamente ficticio, enemigo de Robin Hood, que no aparece asociado a sus aventuras por lo menos hasta 1650 (KNIGHT, 2003: 14). 


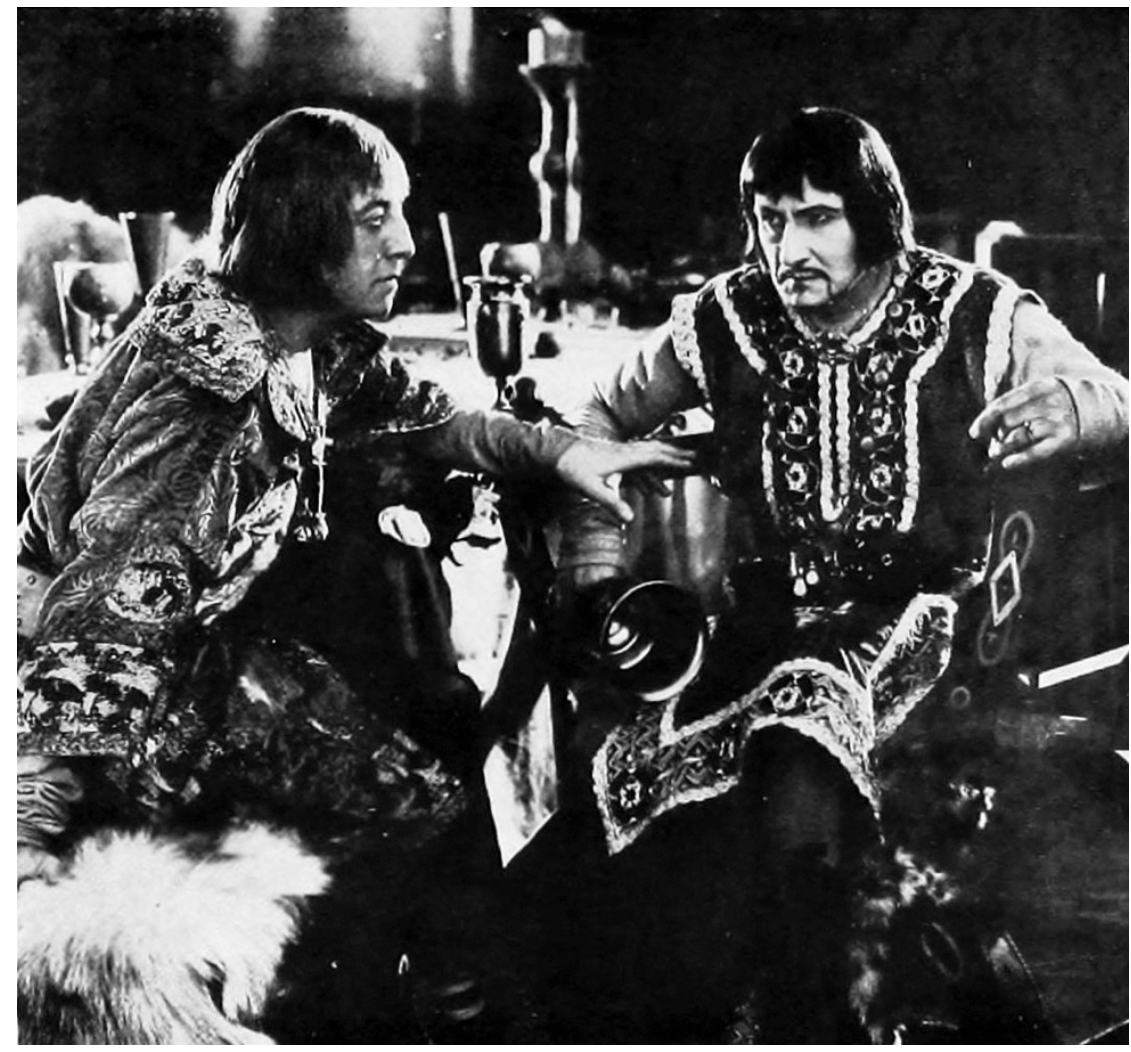

Figura 3. Paul Dickey y Sam De Grasse como Guy de Gisbourne y Juan Sin Tierra en Robin de los bosques (1922). Fuente: Wikimedia Commons. Autor: United Artist. Dominio público.

La segunda media hora constituye la perfecta antítesis de lo que hemos visto en la primera, con una Inglaterra en la que ya se ha quedado Juan en el trono después de la marcha de Ricardo a la Cruzada y con una serie de imágenes completamente diferentes: hileras de ahorcados, malvados recaudadores que toman el dinero mediante el ejercicio de la violencia, expulsión de sus tierras de todos aquellos que no pueden pagar, latigazos y torturas a madres en presencia de sus hijos pequeños, propiedades que arden, cárceles a rebosar de mujeres, niños y ancianos...

Si el contraste entre la forma de actuar de los dos hermanos ya deja muy claro quién es el virtuoso y quién el pérfido a ojos de los guionistas, contiene la versión de 1922 un detalle en el argumento que supone el primero de los elementos difamatorios de Juan que son cosecha exclusiva del séptimo arte: el encargo de Juan a su mano derecha, el noble sir Guy de Gisbourne, de que, una vez esté en Tierra Santa, atente contra la vida de Ricardo, de manera que nunca pueda regresar y él pueda perpetuarse en el trono. Las demás versiones cinematográficas, cuya trama empieza mucho más tarde que en la versión muda con un Ricardo que ya es cautivo de Leopoldo de Austria, no seguirían por esta línea y ninguna volvería a 
acusar a Juan de algo, el intento de asesinato de su hermano, de lo que no hablan ni siquiera los cronistas más críticos con su reinado. ${ }^{11}$

La versión muda protagonizada por Douglas Fairbanks pronto sería reemplazada en el recuerdo por Robin de los bosques (Michael CurTIz y William Keighley, 1938) que, en palabras de Juan Antonio BARRIo (2008: 443) se trata de «una de las más populares y conocidas películas de la Historia del cine y la que más han admirado generación tras generación de espectadores sobre el mítico héroe medieval». En el tema que nos ocupa, la introducción, con no pocas inexactitudes históricas, no tiene desperdicio:

En el año de Gracia de 1191, cuando Ricardo Corazón de León marchó a expulsar a los infieles de Tierra Santa, entregó la regencia de su reino a su amigo Longchamp, en quien tenía plena confianza, en vez de a su pérfido hermano el príncipe Juan. Amargamente resentido, Juan esperó una oportunidad que hiciese caer a su hermano $\mathrm{y}$, así, con la ayuda de los barones normandos, apoderarse del trono. ${ }^{12}$

Tras haber dejado claro antes de la primera escena lo que en la película se piensa de Juan Sin Tierra, al minuto siguiente lo vemos interpretado por el extraordinario Claude Rains recibiendo la noticia de que Ricardo ha sido hecho prisionero en Europa central, alegrándose por ello, declarando que al día siguiente pondría nuevos impuestos y vertiendo una copa de vino que enseguida, mediante un zoom de la cámara, se asimila con el derramamiento de sangre que está por venir. Las escenas siguientes son las de los mismos abusos y torturas que ya habíamos visto en la versión de 1922 en un mundo en el que, literalmente, había «sajones colgando en todos los árboles».

Lois POTTER (1998: 10) ha definido la interpretación que hace Claude Rains en esta película como la de un príncipe «afeminado, arrogante y cobarde». No estoy, en absoluto, de acuerdo con esta lectura, pero lo que sí está claro es que tenemos ante nosotros a un Juan muy diferente al que había encarnado Sam De Grasse en 1922. Si aquel se dejaba dominar por la ira y muy frecuentemente se encontraba ebrio, el Juan Sin Tierra que encontramos en la versión de 1938 es alguien tremendamente cínico, que constantemente está sonriendo mientras va desarrollando los más retorcidos planes en su interior que comenta con sir Guy de Gisbourne y, en definitiva, alguien mucho más atemperado, maquiavélico y capaz de controlar sus emociones e incluso de ser diplomático cuando las circunstancias lo requerían en beneficio de sus intereses.

11 Debe afirmarse siendo justos que la película en ningún momento se presenta a sí misma como un fiel reflejo de lo acontecido, sino que, en un rótulo que se muestra nada más empezar, define la Historia como «a compound of legend and chronicle» y declara abiertamente que «we offer you an impression of the Middle Ages». En adelante, cualquier fragmento en cursiva que no vaya acompañado de una referencia bibliográfica corresponde a una expresión literal, verbal o escrita, de las películas. 12 Puesto que William Longchamp, el canciller de Inglaterra y obispo de Ely con quien Juan Sin Tierra mantuvo una abierta rivalidad durante la ausencia de Ricardo, no es un personaje que haya llamado la atención de los cineastas, no me detendré a hablar sobre él, si bien sí conviene resaltar, frente a la impresión que pueda dar el rótulo introductorio de la película, que, según ha señalado WARREN (1978: 40), Longchamp fue nombrado a toda prisa en el cargo por un Ricardo que estaba impaciente en marchar a la Cruzada y que había visto cómo su primera opción, el conde de Essex, había fallecido. 


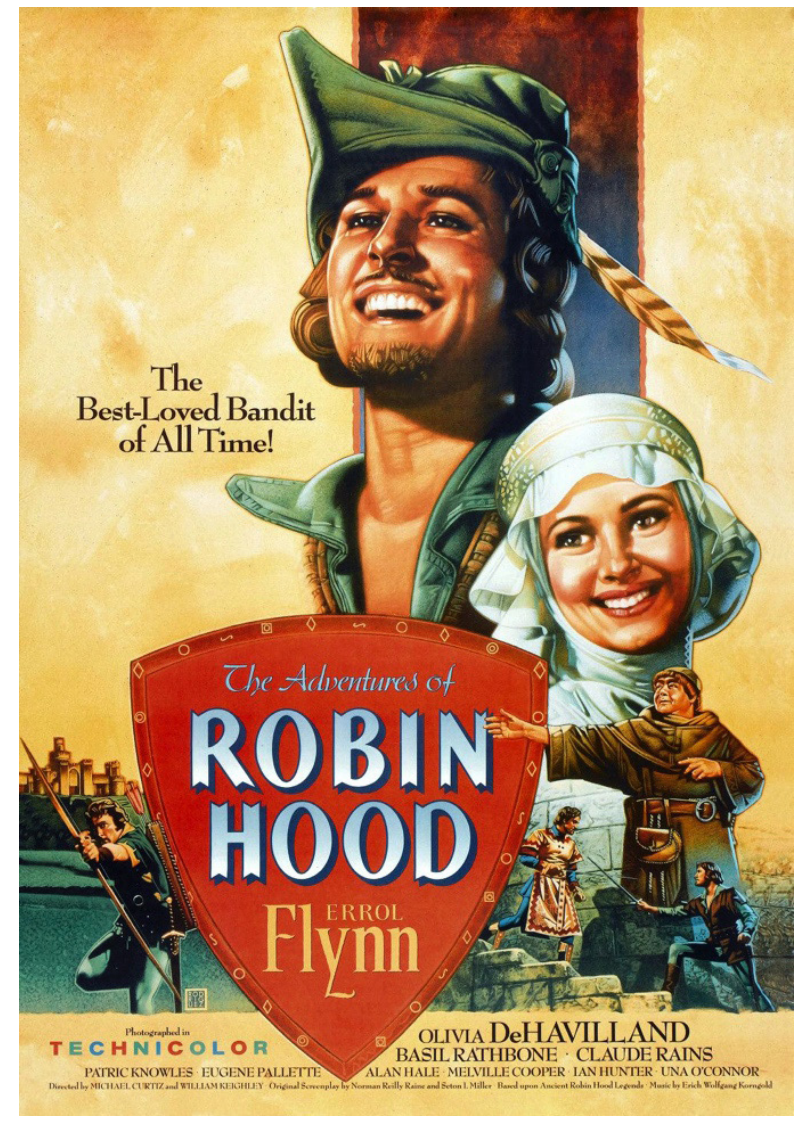

Figura 4. Cartel de Robin de los bosques (1938).

Fuente: Flickr. Autor: Halloween HJB. Dominio público.

Dejando para más adelante algunos otros detalles de interés que contiene esta versión y que comentaré juntamente con otras, Javier Coma le ha dado una simbología a la película consistente en plantear que el regreso de Ricardo representa la esperanza de que llegaran tiempos mejores en los que se superara la crisis económica estadounidense de los años treinta, a la par que identifica a los normandos con los nazis, indica que la escena en que Robin Hood es detenido por los partidarios de Juan sin que nadie lo impida es una alegoría de la pasividad de la población ante el avance de Hitler y, en definitiva, considera el largometraje no como «un ligero y evasivo film de aventuras», sino como «una de las primeras obras de Hollywood contra el nazismo» (ComA, 1995: 139).

Aunque otros autores posteriores también han hecho alusión a lo que decía Javier Coma sin cuestionarlo (AlONSO, MASTACHE y AlOnSO, 2007: 44 y BARRIO, 2008: 445), creo que se trata de una interpretación un tanto forzada que no termino de ver clara en una película que fundamentalmente busca el entretenimiento mediante el espectáculo y por el hecho de que Hollywood, cuando quiso hacer 
referencia a los nazis, lo hizo abiertamente y sin necesidad de ocultarlos bajo ninguna simbología, aunque fuera incluso mezclándolos con personajes de otras épocas. ${ }^{13}$ Con todo, esta interpretación, aun cuando yo no la comparta, no deja de ser interesante y abre un nuevo tema como es el presentismo y la aplicación a un personaje de los siglos XII y XIII de valores propios del siglo XX, lo que creo que sí será más que evidente en algunos de los casos que vendrán después.

La última película de este mítico personaje que tuvo un enorme éxito la pasada centuria y que se centra igualmente en el momento en que Ricardo se encontraba preso es la de dibujos animados Robin Hood (Wolfgang ReITHERMAN y David Hand, 1973). Habrá quien piense que una película de animación no sea algo serio para estudiar este tema. No puedo estar más en desacuerdo con esta interpretación, habida cuenta de que este artículo se centra en qué imagen de Juan Sin Tierra nos ha transmitido el cine y esta película de Disney, que no falta en ninguno de los estudios sobre Robin Hood o incluso sobre el propio Juan que se acuerdan del cine, ha sido vista por millones de personas desde que se realizó.

Al hablar de los libros de literatura infantil y juvenil ya traté cómo es el Juan Sin Tierra de esta película, esto es, un delgado león amante de las joyas y del dinero, siempre acompañado por una serpiente que actúa de consejera y alguien en quien se combinan habilidosas jugadas políticas del estilo de hipnotizar a Ricardo para que acuda a la Cruzada y se aleje de Inglaterra con multitud de ocasiones en que es engañado por los protagonistas. Esta es una de las novedades en la caracterización de Juan Sin Tierra: mientras que en las primeras versiones habíamos visto a un príncipe cruel y maquiavélico, El león en invierno nos mostró a un adolescente inmaduro y ahora DisNEY nos muestra a alguien torpe, ingenuo y con tanta mala suerte que llega a provocarnos incluso lástima y ternura.

De forma extremadamente sencilla, la película está cargada de detalles plenamente llenos de significado. Por un lado, la dicotomía entre los dos hermanos se remarca por el hecho de que, siendo ambos leones y estando ambos doblados por el magistral Peter Ustinov, Ricardo tenga una frondosa melena negra de la que carece Juan, lo que confiere al primero una apariencia física mucho más acorde para el ejercicio del poder que la que tiene el segundo.

Por otro lado, el hecho de que, en distintos momentos de la película, Juan se chupe el dedo es lo que más ha llamado la atención de los especialistas a la hora de remarcar su cobardía (POTTER, 1998: 218 o SEEL, 2012: 7). Lo que en la versión en cómic que he citado al principio se simplifica como un gesto al que recurre Juan para expresar su frustración cuando algo le ha salido mal, en la película se va mucho más allá y se deja intuir un claro temor a la madre e incluso un sentimiento de tristeza cuando dice «Mami siempre quiso a Ricardo más que a mí».

Aunque frecuentemente se haya cuestionado -de forma acertada en la mayoría de los casos, no lo niego- la veracidad de las películas de DisNey a la hora de reconstruir el pasado, no se puede negar que, en este caso, hace lo que hasta el momento no había hecho ninguna de las películas de Robin Hood, esto es, concederle protagonismo a una Leonor de Aquitania que seguía viva mientras todo esto sucedía y cuyo desapego hacia su hijo pequeño influyó enormemente en su carácter y en, como afirmaba Régine PERNOUD (2009: 221) «esa inestabilidad

13 Sirvan de ejemplo tres películas de Sherlock Holmes rodadas en 1942 y 1943 por la productora Universal que enfrentaban al mítico detective -interpretado precisamente por Basil Rathbone, el que da vida a Gisbourne en Robin de los bosques- con los nazis, lo que nunca sucedió en ninguno de los relatos de un Arthur Conan Doyle que había ya fallecido en 1930. 
propia de la casta de los Plantagenet, que en él se convertiría en neurosis».

Sin embargo, creo que el elemento más difamatorio hacia Juan Sin Tierra -probablemente, de toda la historia del cine- no se encuentra tanto en todos estos gestos que vemos hacer al león que lo interpreta, sino en una canción cuya letra merece ser destacada íntegramente y que no necesita comentarios adicionales:

A un rey inglés todos cantarán, en los siglos que vendrán, más no por ser un gran monarca o por saber reinar.

Mientras el buen rey Ricardo a las Cruzadas fue a pelear, tenemos que aguantar a un tirano súper Juan.

Y cuando la Historia hable de él, dirá que fue torpe, inútil y cruel el que hoy es el rey inglés pelele...el que hoy es el rey inglés pelele.

Se siente rey solo por vivir en el palacio real, se sienta en el trono a pensar a quién hacer el mal.

Los berrinches son su fuerte, eso sí lo sabe hacer y después el pulgar se chupa y llora llamando a su mamá.

Él dice que Juan I es y Juan el rey cero más bien es, le dicen el rey inglés pelele.

Mientras sube los impuestos y nos roba nuestro pan, el rey ausente intenta usar corona y cetro real.

Pero mientras haya hombres como el noble Robin Hood, lo harán pagar por la crueldad y al pueblo ayudarán.

Por mucho que lo quieran cuidar, desnudito lo vamos a dejar...el poco más que loco rey pelele.

El pícaro cínico, maniático ideático, colérico histérico, pálido escuálido, chinche berrinche, cerdo lerdo, el súper Juan es el rey inglés pelele.

\subsection{Walter Scott, Ivanhoe y sus adaptaciones cinematográficas}

En diciembre de 1819, sir Walter Sсот, considerado por muchos como el padre de la novela histórica publicó Ivanhoe, convirtiéndose en uno de los libros más leídos por numerosas generaciones a lo largo de estos doscientos años y calando en la conciencia de sus lectores mucho más que cualquier ensayo, artículo o libro que hayamos podido escribir muchos historiadores medievalistas. ${ }^{14}$

Sin entrar a profundizar demasiado sobre el argumento, una rivalidad entre sajones y normandos que, en realidad, ya no existía a finales del siglo XII es el telón de fondo en el que sir Wilfred de Ivanhoe lucha por la restitución de Ricardo en el trono frente al usurpador de su hermano Juan, que se ha apoderado del trono. Esa lucha se llevará a cabo en el bosque y mediante el asalto de fortalezas de los partidarios de Juan, labor con la que el héroe contará con la ayuda de encapuchados y misteriosos caballeros que no revelan su identidad y que se tratarán realmente de los mismos Robin Hood y Ricardo actuando en la clandestinidad contra el tirano.

14 Aunque ciertamente la popularidad de Ivanhoe ha decaído bastante en el siglo XXI, lo cierto es que podemos hablar de un fenómeno cultural de los siglos XIX y Xx por, entre otras cosas, «la rebelión, el desafío al orden instituido, especialmente cuando es injusto; la camaradería o amistad en pro de un ideal común; el arrojo ante el peligro, la generosidad con los débiles...» (HERnÁNDEZ y SÁnCHEZ, 1996: 7). 


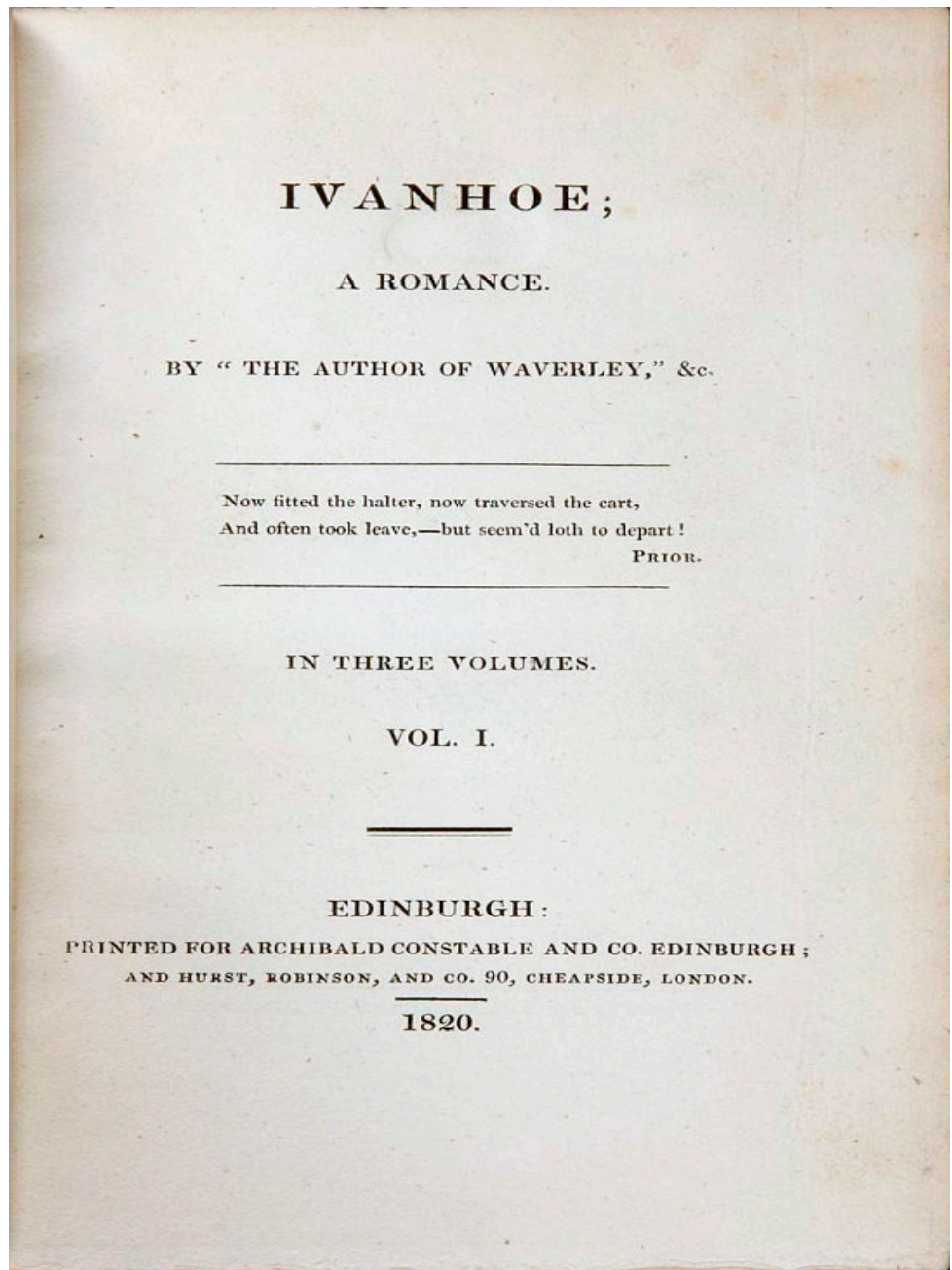

Figura 5. Portada de la primera edición de Ivanhoe (1820), de Walter Scott. Fuente: The Early Modern Center. Autor: No consta. Dominio público.

Aunque ciertamente Juan Sin Tierra no aparece en realidad demasiado en la novela, cuando lo hace recibe las mismas descripciones descalificativas a las que ya estamos acostumbrados:

El príncipe Juan odiaba y despreciaba a las pocas familias sajonas de importancia que aún perduraban en Inglaterra y no dejaba pasar la oportunidad de mortificarlas y afrentarlas, consciente de que su persona y pretensiones no eran de su agrado ni tampoco de la mayor parte del pueblo llano, que temía innovaciones en sus derechos y libertades de un soberano tan licencioso e inclinado a la tiranía como el príncipe Juan.

Acompañado por su galante séquito, montado en un buen caballo y espléndidamente 
vestido de carmesí y oro, con un halcón en la mano y la cabeza cubierta por un rico gorro de pieles adornado con un círculo de piedras preciosas, del que salía su larga y rizada cabellera para cubrirle los hombros, el príncipe Juan caracoleaba dentro del palenque a la cabeza de su jovial grupo sobre un gris y fogoso palafrén, se reía sonoramente y observaba al mismo tiempo con el descaro de un experto a las bellezas que adornaban las gradas altas (SСOTT, 2013: 164-165). ${ }^{15}$

Si prescindimos aquí de una primera versión de 1913 dirigida por Herbert BRENON en la que Juan Sin Tierra, interpretado por George Courtenay, aparece caracterizado como alguien en quien se combina tanto la maldad por secuestrar a los judíos Isaac de York y a su hija Rebeca como el pavor cuando alguien le nombra a su hermano Ricardo, la versión por excelencia que cualquier cinéfilo conoce es la que, bajo la dirección de Richard THORPE, protagonizaron en 1952 Robert Taylor como Ivanhoe, Elizabeth Taylor como la judía Rebeca, Joan Fontaine como lady Rowena y Guy Rolfe como el príncipe Juan.

Wilfred L. WARREN señaló cómo la caracterización de Juan Sin Tierra ha ido cambiando a lo largo de los siglos en función de las mentalidades, ideologías y predilecciones políticas de cada momento, de manera que, a la visión tremendamente negativa construida por el clero a comienzos del siglo XIII, se le podría contraponer la que dieron de él los historiadores del periodo Tudor a los que fascinaron los enfrentamientos que Juan I de Inglaterra mantuvo con el Papado, imagen esta que fue postergada en el siglo XIX en beneficio de unos valores morales que no casaban con los comportamientos de este monarca (WARREN, 1978: 15-16). La caracterización moldeable del rey, anacrónica y ajustada a las mentalidades del siglo xx, es algo que se aprecia con claridad en el cine de los años cincuenta y, muy especialmente, en Ivanhoe.

Si la imagen general que confiere Guy Rolfe al personaje no difiere de otras versiones en tanto en cuanto nos encontramos a alguien hosco, malhumorado, intrigante y traidor que no duda en censurar a sus partidarios cuando ve cómo todos ellos son derrotados por un misterioso caballero en un torneo -el propio Ivanhoe, como es fácil imaginar- para goce y disfrute de un público que odia a Juan y a sus seguidores, el largometraje acaba derivando, como afirmó SREBNICK (1999: 47), en un producto de la Guerra Fría y del macartismo.

En primer lugar, la dicotomía entre hermanos se eleva al máximo nivel. Por un lado, Ivanhoe busca incesantemente obtener el dinero necesario para rescatar a Ricardo, a quien presenta como alguien con valores democráticos que tiende su brazo a todo el mundo con la noble intención de congeniar a todos en la nueva Inglaterra que surgirá a su regreso. Obtenido el rescate de Ricardo de manos de la comunidad judía a través del personaje de Isaac de York, Juan aparece en contraposición como alguien que expresa que no se puede confiar en quienes van pactando con los judíos, a donde parece dirigirse la política de Ricardo por el simple hecho de haber sido liberado con su dinero. ${ }^{16}$

Si se examinan los acontecimientos que estaban teniendo lugar por aquel entonces y se repara en la creación del estado de Israel en 1948, el apoyo decidido

15 Se trata, lógicamente, del año de la edición consultada, al igual que sucede más adelante cuando cite a William Shakespeare.

16 No es cierto que fueran los judíos los que pagaran el rescate de Ricardo, puesto que este se obtuvo fundamentalmente, como ha indicado GiLlingHAm (2012: 379), con un tributo del 25\% sobre los ingresos y los bienes muebles, además de «toda la producción de lana de un año de los monasterios cistercienses así como todo el oro y la plata de las iglesias de todo el país». 
que los Estados Unidos dieron a este proyecto y los enfrentamientos que se habían producido ya en 1949 entre judíos y árabes, se entiende mucho mejor cómo Ricardo y Juan se ponen en esta película a plena disposición de la política del momento, con un Ricardo presentado como un demócrata que acoge a todos y que agradecerá a la comunidad judía la ayuda recibida para su liberación y un Juan, malvado para no variar, que personifica a todos aquellos que desconfían o se oponen a dicha alianza.

En segundo lugar, resulta sumamente interesante un nuevo elemento desfavorecedor con el que esta película de 1952 sobrecarga a Juan Sin Tierra. En la novela de Walter Sсотт, el templario Brian de Bois-Guilbert, enamorado de Rebeca, la secuestra y su comunidad considera que este ha sido embrujado por ella, motivo por el cual es sometida a juicio y condenada a muerte por las autoridades eclesiásticas. En la película, la Iglesia se ve totalmente ausente de implicación en este suceso, el templario al que interpreta George Sanders se convierte en un simple caballero normando y el proceso pasa a estar encabezado por aquel en quien se concentra todo lo negativo de la película, esto es, un príncipe Juan caracterizado, en palabras de CAMPANILE (2019:212) como «sardonico e crudele al limite della caricatura».

No sería esta la única versión de la novela creada por Walter ScotT que fue llevada al cine, puesto que en 1971 se estrenó una película italiana titulada La espada normanda, que fue dirigida por Roberto Mauri y que contó con Mark Damon interpretando a Ivanhoe. Con todo, este largometraje se ambienta en los años inmediatamente posteriores a la muerte de Enrique I, esto es, en la década de los treinta del siglo XII, por lo que no resulta de utilidad en lo que respecta a este artículo.

\subsection{Juan Sin Tierra ante el regreso del rey Ricardo}

Antes de pasar a la siguiente etapa, quedaría pendiente tratar el desenlace común de todas estas películas, como fue el regreso de Ricardo Corazón de León a Inglaterra en 1194 y lo que sucedió con su hermano Juan, puesto que estamos hablando en este caso de una nueva distorsión histórica evidente.

Sin profundizar en grandes detalles y recorriendo las películas mencionadas en este apartado en orden cronológico, Robin de los bosques (1922) entronca incluso con el cine cómico de la época y, aludiendo de forma clara a que con Ricardo ha vuelto la alegría a Inglaterra tras una etapa de sombras, Juan es elevado por los aires por su hermano en un alarde de fuerza producto del imponente físico del actor Wallace Beery y expulsado del castillo, sin más. En Robin de los bosques (1938), después de que Ricardo haya obligado al desarme a todos sus enemigos, Juan es desterrado. Ivanhoe (1952) se muestra mucho más cauta con esta cuestión y tan solo nos muestra a Juan Sin Tierra arrodillándose ante Ricardo en señal de sumisión cuando éste aparece con todos sus hombres al concluir el duelo final. Finalmente, en Robin Hood (1973), el león Juan y su consejera la serpiente aparecen picando piedra en una cantera vestidos como presos y con bolas de hierro encadenadas a sus cuerpos.

Frente a todos estos finales enormemente dispares, el cronista Roger de Howden muestra una versión de los hechos completamente distinta. Citando los pasajes que Kate NorGATE (1902: 52) resaltó sobre esta cuestión, ambos hermanos 
se habrían reencontrado dándose un beso fraternal, Ricardo habría perdonado inmediatamente a Juan achacando todo a sus malos consejeros («Think no more of it, John! You are but a child, and were left to ill guardians. Evil were there thoughts who counselled you amiss. Rise, go and eat»), proponiéndole acto seguido que tomaran una cena («he added, turning to their host, 'what can he have for dinner?'») que consistió en un salmón que «Richard immediately ordered it to be cooked for his brother». ${ }^{17}$

Aunque más adelante haré alguna alusión a los cronistas del periodo y a su fiabilidad, creo que seríamos ingenuos si nos creyéramos una versión tan edulcorada de los acontecimientos de manos de los que no pretendían otra cosa más que ennoblecer todo lo que hacía Ricardo y que tanto contrasta con la abierta difamación hacia Juan de la que han hablado otros autores; ${ }^{18}$ sin embargo, justo es reconocer que el cine exageró notoriamente e incluso falseó el devenir de una persona a quien Ricardo acabó perdonando y que, en líneas generales, colaboró con él desde 1194 hasta que se produjo su fallecimiento en 1199.

\section{JUAN SIN TIERRA, REY DE INGLATERRA (1199-1216)}

Aunque indudablemente no tanto como durante el cautiverio de Ricardo, Juan I siguió interesando a los cineastas durante la etapa en la que fue rey de Inglaterra, periodo en el cual, al no poder explotarse ya el recurso del contraste entre él y su hermano, se recurre a otros elementos de difamación que, como norma general, se centran en el contexto de la elaboración de la Carta Magna.

Resulta un tanto sorprendente que no se haya sacado más partido por parte de sus detractores a una de las etapas probablemente más desafortunadas del reinado de Juan Sin Tierra, los primeros años del siglo xIII, en los que se produjo, entre otras cosas, el asesinato de su sobrino Arturo i de Bretaña -promovido por él, según informaciones de la época aunque sin ninguna prueba real que lo confirmey la pérdida inglesa de Normandía en lo que puede verse como un preludio más o menos claro de lo que sucedería en Bouvines en $1214 .{ }^{19}$

\subsection{William Shakespeare y su The life and death of King John}

El reinado de Juan I de Inglaterra y, en especial, los acontecimientos a los que he hecho referencia en el párrafo anterior llamaron la atención del genial

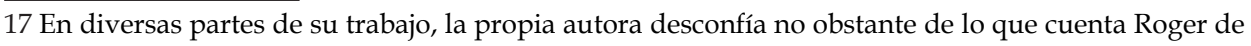
Howden.

18 Por citar un ejemplo, son varios los que aluden a la incapacidad que Ricardo veía en Juan a la hora de conquistar tierras por sí mismo como tuviera un serio oponente delante (NORGATE, 1902: 45 y GILLINGHAM, 2012: 375-376). Por otra parte, como ha señalado GiLlingham (2012: 489), fue muy habitual dentro del juego político del momento la labor de hostigamiento desempeñada por el rey de Francia, Felipe II, para buscar el constante deterioro de la relación entre ambos hermanos.

19 No todos los historiadores han valorado negativamente esta pérdida de territorios ingleses en el continente, puesto que, como señala AuReLl (2012: 27), en el siglo XIX varios de ellos, aun calificando a Juan I de incompetente, consideraron que a Inglaterra no le vino mal deshacerse de la pesada carga de Normandía. 
dramaturgo inglés. En su obra se aborda directamente la disputa entre Juan y Arturo, a quien el rey de Francia apoya como heredero legítimo del trono inglés. Inventándose también un hijo ilegítimo de Ricardo, esta se desarrolla concediendo protagonismo a la guerra que tiene lugar a continuación entre todas las partes implicadas y que se salda con Arturo saltando al vacío.

Quizá porque esta obra ha quedado tan eclipsada en comparación con otras y aunque se siga representando actualmente en teatros como, por otra parte, sucede con todo lo que salió de la pluma de Shakespeare, el cine apenas le ha prestado atención a la misma y la única contribución reseñable es King John (PFEFFER, DicKSON y BEERBOHM, 1899), por otra parte y como ha señalado HAMILTON (1973: 455), la primera adaptación cinematográfica de la historia de una obra de Shakespeare.

No me detendré excesivamente habida cuenta de que se trata de una película prácticamente desconocida, nada influyente en el gran público y de la que se conservan apenas unos escasos fotogramas discontinuos que muestran a Juan intentando convencer al conde de Kent para que asesine a un Arturo que se encuentra arrodillado ante ellos o la muerte del propio monarca descrita por él mismo, según inventó Shakespeare (1968: 209), como «envenenado, muerto, abandonado, perdido». ${ }^{20}$

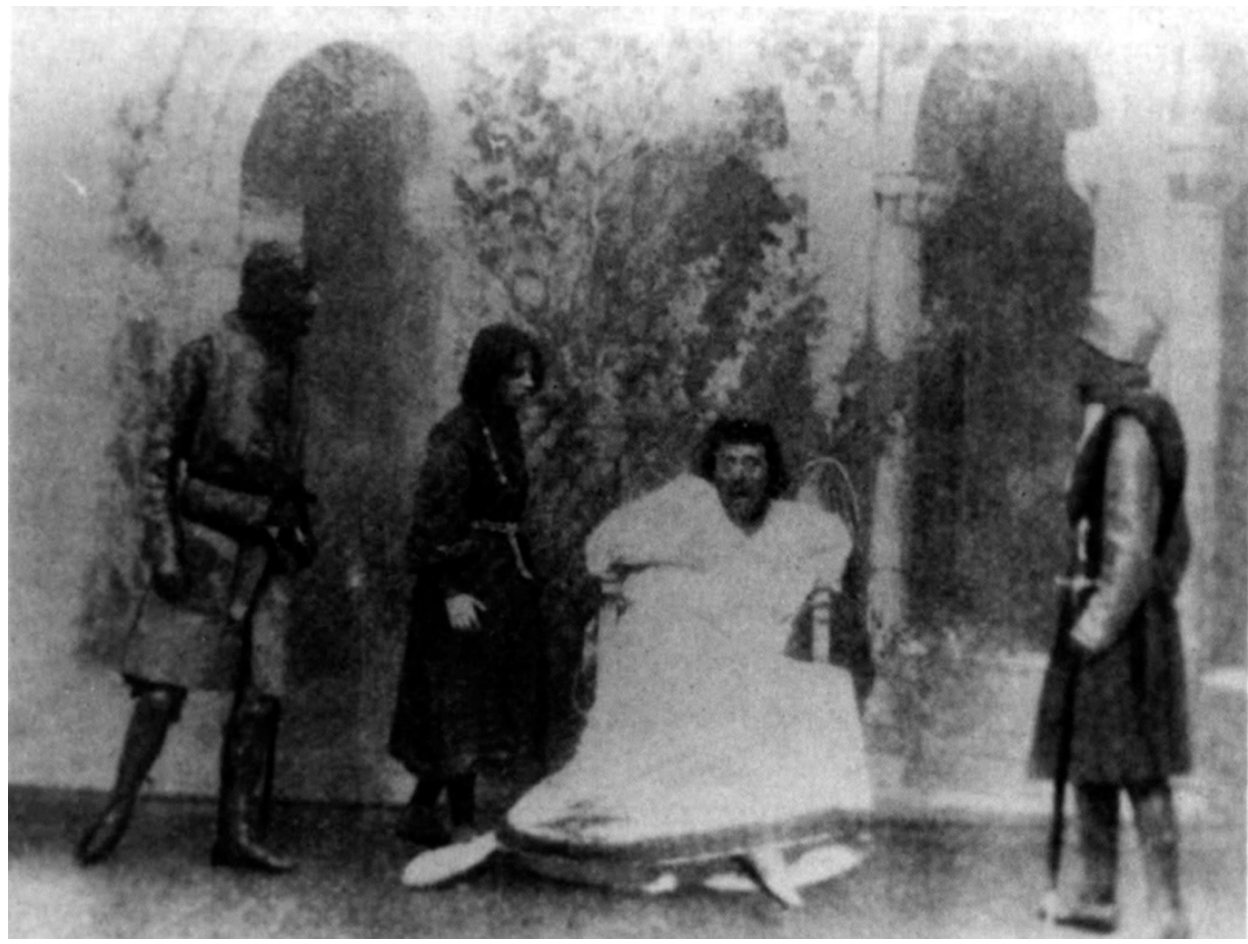

Figura 6. Fotograma de King John (1899) con la muerte de Juan Sin Tierra. Fuente: Wikimedia Commons. Autor: British Mutoscope and Biography Company. Dominio público.

20 Aunque no parece que esto sucediera, hay que señalar que, a la muerte de Juan i en octubre de 1216, sí circularon diversos rumores que apuntaron a un envenenamiento (GIVEN-WILSON, 1996: 87). 


\subsection{Robin Hood y sus descendientes contra el rey Juan}

En esta nueva etapa, es de nuevo Robin Hood y sus historias las que nos permiten seguir viendo a Juan Sin Tierra en la gran pantalla, incorporándose en esta ocasión diversos descendientes de ambos sexos que responden al gusto de Hollywood en la época por atribuir hijos e hijas a personajes tan dispares como el mítico arquero inglés, el conde de Montecristo o incluso Drácula y Frankenstein, por citar tan solo unos pocos casos. Centrándome en primer lugar en el propio Robin Hood, dos películas notablemente famosas merecen nuestra atención.

La primera de ellas, Robin y Marian (Richard LESTER, 1976), rodada entre Zamora y Navarra, es ante todo una comedia provista de numerosas situaciones absurdas que cobra pleno sentido en un momento, los años sesenta y setenta, en los que el cine de reconstrucción histórica había apostado por una desmitificación profunda, irreverente y no siempre bien comprendida de muchos acontecimientos de nuestro pasado por multitud de motivos, entre los cuales A. L. Hueso (1996: 291) destaca «la influencia de las nuevas tendencias historiográficas (la búsqueda de una auténtica historia interna, la preocupación por las mentalidades, la recuperación de los hechos cotidianos como reflejo de una forma de vida) a lo que vino a unirse también la revitalización de la novela histórica».

La labor desmitificadora del largometraje se pone de manifiesto en la visión que se da de Ricardo Corazón de León, interpretado por Richard Harris, como alguien extremadamente sádico y violento, que no tiene ningún reparo en ordenar el asalto e incendio de un castillo, que presume de haber asesinado a todas las mujeres y niños que se encontraban en él, que ordena la ejecución del médico que le atiende por haber recibido el flechazo que le arrebataría la vida y que manifiesta odiar tanto a Inglaterra como a sus padres. Independientemente de que podrían matizarse todos estos detalles, no cabe ninguna duda de que estamos asistiendo a una visión radicalmente diferente de Ricardo a la que hasta el momento nos habíamos acostumbrado, excepción hecha de Anthony Hopkins en El león en invierno. ${ }^{21}$

En lo que se refiere al rey Juan, Ian Holm en esta ocasión, su intervención es muy escasa, pero es suficiente para que cause rechazo al espectador en tanto en cuanto se afirma que no sale de la cama en la que está con una reina que destaca por su enorme juventud. Cuando aparece en escena, después de que haya pasado más de una hora de película, nos encontramos a alguien de muy baja estatura, histérico, con un odio manifiesto hacia el clero, al que le tienen que ayudar a desvestirse y que, efectivamente, no se despega de la reina ni aún en las campañas militares, como se sugiere por parte de una jovencísima Victoria Abril que interpreta a una Isabel de Angulema que cubre su desnudez con ropa de cama y que pregunta al rey cuándo va a terminar para que acuda con ella al interior de una tienda. ${ }^{22}$

La segunda de las películas a las que hacía referencia es Robin Hood (Ridley

21 El desmesurado ejercicio de la violencia más allá de lo habitual en contextos bélicos, una de las acusaciones recurrentes lanzadas contra Juan como muestra de su especial crueldad, es algo que diversos historiadores han apuntado también en Ricardo (JoTISCHKY, 2008: 421). Con respecto a Ricardo Corazón de León en el cine y la literatura y su progresiva visión desmitificadora, véase (RodRíGUEZ, 2020).

22 Con respecto al carácter de Juan Sin Tierra, Gillingham (1999: 4), citando los estudios de James Clarke Holt, destaca cómo tampoco existe unanimidad al respecto, puesto que algunos cronistas dicen que casi siempre estaba histérico, mientras que otros lo describen como más calmado. 
Scotт, 2010), posiblemente una de las que más invenciones contiene puesto que comienza falseando la realidad como si la tercera Cruzada todavía estuviera activa en 1199 y como si Ricardo hubiera perdido la vida en una batalla de la misma; continúa dando una visión negativa de los franceses como si ellos fueran los que querían invadir Inglaterra cuando lo que había sucedido era lo contrario y finaliza con un rey Juan i que se niega a firmar la Carta Magna -presentada aquí como si se tratara de una actual constitución que garantizaría el derecho de los ciudadanos- y que la quema en público.

En lo que se refiere al rey, la necesidad de adaptarse a los gustos actuales para atraer al gran público hace que esté interpretado por el guatemalteco Óscar Isaac, una de cuyas primeras apariciones es haciendo el amor con la reina -una Léa Seydoux veinteañera en esta ocasión ante el rechazo que hubiera generado una adolescente como sí lo era Victoria Abril en Robin y Marian y como lo era entonces una Isabel de Angulema que tenía doce años-, levantándose de la cama ante la requisición de su madre y mostrando a la cámara un vientre plano y un pecho perfectamente depilado. Aunque tenga rasgos maniáticos, el Juan Sin Tierra que interpreta Óscar Isaac no resulta desagradable y, con este giro argumental tan sorprendente, llega a ser percibido incluso como una víctima al que no le queda otro remedio más que defenderse por tener sus territorios invadidos.

Por otra parte, no fue solo Robin Hood a quien encontramos en el cine enfrentado a la monarquía, sino también, como decía antes, a sus descendientes. Dejando de lado todos aquellos largometrajes en los que el hijo o hija de Robin no se enfrentan al rey Juan o que, haciéndolo, se trata de películas muy desconocidas, ${ }^{23}$ el ejemplo quizá más sobresaliente ha sido El temible Robin Hood (Gordon DougLAs, 1950), protagonizada por su hijo pese a que este sea el título.

Ambientada en la parte final del reinado de Juan I, esta se trataría también de una de las películas producto de la Guerra Fría que, como afirmaba Walter SREBNICK sobre Ivanhoe, adaptaron sus mensajes a la época en la que se produjeron independientemente de en qué momento estuvieran ambientadas. Interpretado en esta ocasión por George Macready, el rey Juan es alguien que aumenta tiránicamente los impuestos, que está en contra de la democracia -literalmenteque quieren imponerle los barones del reino y que, en su enfrentamiento con ellos, no tiene reparo incluso en aliarse con los enemigos exteriores a la patria, personificados aquí en el conde de Flandes, a fin de arraigarse en el poder.

Si la película no es diferente de otras en lo que se refiere a la caracterización prototípica del rey Juan, sí que resulta especialmente interesante el papel que desempeña aquí el arzobispo de Canterbury Stephen Langton (Donald Randolph) como el mayor representante de la democracia que pueda imaginarse frente a un rey tiránico al que indica, justo antes de que firme la Carta Magna, que, por su forma de actuar, ha perdido la capacidad de reinar por la gracia de Dios.

Efectivamente, como señala Aurell, el antagonismo entre el clero inglés y la monarquía angevina, que arrancaba en los tiempos de Enrique II con el asesinato de Thomas Beckett y que había aumentado durante el cautiverio de Ricardo con acusaciones a una Iglesia que había permitido que un cruzado hubiera sido

23 Aquí podrían citarse El hijo de Robin de los bosques (Henry Levin, 1946) en la que se enfrenta a un malvado Guillermo el Mariscal que aleja del poder al niño Enrique III; The son of Robin Hood (George Sherman, 1958) en la que no aparece Juan o Princess of thieves (Peter Hewitt, 2001) en la que la protagonista, la popular Keira Knightley, dedica su lucha a buscar al hijo secreto de Ricardo que inventó la tradición shakespeariana. 
retenido en contra de su voluntad y que no había hecho nada por su liberación (BARLOW, 1988: 361), se había recrudecido notablemente por el entredicho declarado por Inocencio III a Inglaterra en 1208 y la posterior excomunión del rey en 1209 , mantenida hasta 1213.

Nada tienen que ver los enfrentamientos entre el rey y la Iglesia con una defensa por parte de esta de anacrónicos ideales democráticos ni nada parecido, sino que todo formó parte de una estrategia en la que, como ha señalado AurELL (2012: 405), la Carta Magna supondría no solo el triunfo de las pretensiones de la nobleza, sino también de una Iglesia que, de esta manera, evitaba cualquier injerencia del rey en los asuntos eclesiásticos.

\section{REFLEXIONES SOBRE LA PERSONALIDAD DE JUAN SIN TIERRA}

Como sucede con tantos personajes históricos, nunca ha habido unanimidad respecto a la personalidad de Juan Sin Tierra y sí, en cambio, numerosas ideas preconcebidas que se han ido repitiendo por unos y otros sin llegar realmente a cuestionarse su validez. Ya he señalado cómo algunos autores indicaron cómo la caracterización que se hizo de Juan i de Inglaterra fue adaptándose a lo largo de los siglos a las circunstancias políticas o valores morales de cada periodo, aunque con un claro predominio de la visión negativa o descalificadora. De igual modo, la dicotomía entre el hermano bueno y el hermano malo de la que hablaba Frank MCLYNn existió ya en la Edad Media, pero creo que mucho más matizada de lo que sería después, especialmente a partir del Romanticismo cuando, gracias fundamentalmente a Walter SCOTT, sí se abre una brecha entre ambos personajes.

Sin ánimo de entrar en una relación exhaustiva de detalles que también convertían a Ricardo Corazón de León en impopular y obviando aquí sus controvertidas acciones llevadas a cabo en Tierra Santa, ya existían leyendas en la época que afectaban a todos los miembros de su familia en general y a Ricardo en particular, como el hecho de que se dijera que se había puesto a sangrar cuando vio el cadáver de su padre, lo que, según la mentalidad de la época, equivalía a ser identificado como el asesino (AURELL, 2012: 68-69). En un terreno mucho más mundano, aunque la literatura y el cine han identificado a Juan como el que llevó a cabo todas estas acciones, el propio Ricardo fue el primero que, nada más ser coronado rey en 1189, había decretado una importante subida de impuestos ante su necesidad de acudir a la Cruzada (SEEL, 2012: 21), lo que resulta difícil de encajar con el hecho de que gozara de muy buena fama entre sus súbditos.

Paralelamente, y aunque estaríamos faltando a la verdad si dijéramos que Juan no tenía mala fama en la época o que no generara desconfianza en algunos sectores, WARREN (1978: 9-10) ha destacado testimonios que apuntan a que no se tenía en la época ninguna sensación de que Juan I fuera más cruel que el resto. Si, en mi opinión, se puede afirmar pues que el primero conde de Mortain y después rey de Inglaterra no era diferente de sus contemporáneos, cabe preguntarse el por qué de toda esta especial difamación.

Los cronistas parecen ser la clave de todo. Fueron los cronistas los que glorificaron al máximo a Ricardo, contando todo tipo de hazañas sobre él y presentándolo como un héroe, especialmente un Roger de Howden que depura los aspectos más negativos de su figura o un Ricardo de Devizes que tampoco le señala ningún defecto y que califica de perfecto todo lo que hacía (JoTISCHKY, 2008: 
425). Fueron también los cronistas los que, en muchos aspectos, minimizaron la influencia y la labor ejercida por Leonor de Aquitania cuando está sobradamente demostrada su implicación a la hora de intentar resolver todas las crisis políticas que tuvieron lugar hasta su fallecimiento en $1204 .{ }^{24}$ Sin ningún género de dudas, fueron también los cronistas los que crearon desde el primer momento una imagen muy negativa de Juan Sin Tierra y esto se debió, en gran medida, a que, frente al héroe que acude a la Cruzada a luchar contra el infiel, en esta ocasión tocaba hablar de alguien abiertamente enfrentado al clero inglés y al todopoderoso Inocencio III.

Considerando que Juan I de Inglaterra no fue el protagonista de grandes gestas envueltas en lo mítico, que los principales cronistas que habían ensalzado a Ricardo fallecieron a comienzos del siglo XIII y que, como han señalado diversos especialistas, todos estos autores no eran más que monjes extremadamente críticos con cualquier cosa que hiciera un rey que durante varios años estuvo excomulgado (WARREN, 1978: 9 y SEEL, 2012: 4-5), se comprenden las razones por las cuales se construyó la imagen de alguien que, en ocasiones, parece ser más un monstruo que un ser humano.

\section{CONCLUSIONES}

Podrá pensarse que el cine no es más que entretenimiento que no tiene en cuenta la realidad histórica ni la fidelidad a los hechos que se representan, lo cual yo mismo he puesto de relieve al comentar algunas películas. Con todo, no es menos cierto que desde hace tiempo son cada vez más los medievalistas que lo tienen en cuenta a la hora de valorar una percepción más -no necesariamente ni la mejor ni la peor, sino simplemente una más- sobre nuestro pasado, aunque sea, como ha señalado J. A. BARRIO (2008: 431) «ante el estupor y la incomprensión de compañeros y colegas».

En lo que se refiere a Juan I de Inglaterra, si se admite que la distorsión de su imagen ya había comenzado en realidad en la propia Edad Media, ciertamente no puede acusarse ni a la literatura ni al cine de ser los creadores de una difamación que ya en realidad ya existía, aunque sí puede afirmarse que la acentuaron notablemente. Quizá por haber sido convertido en la ficción en el principal antagonista de personajes famosos como Robin Hood o como Wilfred de Ivanhoe; por haber tenido la suerte o la desgracia de haber tenido un hermano envuelto en la leyenda o por haber sido presentado en diversos momentos del siglo xx como algo equiparable al nazismo o al comunismo, no cabe ninguna duda de que nos encontramos ante uno de los reyes medievales más famosos de la historia, que no por ello bien conocido o incluso valorado con un mínimo de ecuanimidad.

De entre todos los elementos que alguien no experto en la materia tiene en la actualidad para acercarse a la figura de Juan Sin Tierra, el cine es, sin ningún género de dudas, la que más atracción despierta hoy en día. Aunque pueda ser duro reconocerlo, prácticamente nadie lee ni conoce ya a ningún cronista del siglo XIII como no sea un especialista de alto nivel. En la actualidad, Walter ScotT va

24 Además de las referencias que ya he citado sobre Leonor de Aquitania, para obtener una visión de conjunto sobre las acciones de la reina en las diferentes crisis políticas que fueron surgiendo es extremadamente útil HivERGNEAUX (2000: 79-83). Con respecto a su constante lucha para procurar la liberación de Ricardo, la cuestión queda bien sintetizada en FLORI (2001: 221). 
quedando relegado al olvido, sus novelas ya no se leen tanto como antes y el segundo centenario de la publicación de Ivanhoe ha pasado bastante desapercibido para muchas instituciones culturales. Es posiblemente el cine lo que queda y la imagen que de Juan Sin Tierra se ha ofrecido en la gran pantalla -sin olvidar la televisión- es lo que, sin duda, ha quedado mejor grabado en nuestras retinas, por muchas inexactitudes que se hayan podido cometer.

Los estudios sobre cine y los estudios sobre historia siguen siendo todavía quizá demasiado autónomos y los unos tienden a ignorar a los otros. Muchos historiadores siguen sintiendo una enorme desconfianza ante lo que el séptimo arte puede ofrecer y consideran de forma completamente equivocada que un cineasta nada tiene que decir en lo que se refiere a la interpretación del pasado. Por el contrario y en el otro extremo, no poca bibliografía sobre cine y sobre técnicas cinematográficas tiende a hablar tan solo de aspectos técnicos relacionados con lo estrictamente audiovisual y, cuando abordan el cine histórico, minusvaloran la veracidad, algo que no debe ser lo único ni siquiera lo principal a valorar, pero que considero que tampoco debe ser un elemento que se tome a la ligera si queremos hablar de buenas recreaciones de nuestro pasado en un sentido amplio y no solo parcial.

J. Montero (2008: 138) apuntaba la necesidad de que unos y otros aprendan a convivir. Creo que ahí está la clave, en los puntos medios que siempre existen entre tendencias muy contrapuestas y en la búsqueda de un equilibrio. Juan Sin Tierra ha sido claramente demonizado a lo largo de todo el siglo xx por el cine, pero esto ya había sucedido mientras todavía vivía. Puede que la interpretación de Sam de Grasse o de Claude Rains nada tenga que ver con la realidad, pero probablemente tampoco la caracterización que del monarca construyó un clérigo del siglo XIII cuya única intención era minarlo políticamente.

El cine no actúa en esta ocasión más que como un elemento más de interpretación de nuestro pasado. Al historiador es al que le corresponde valorar y juzgar cómo se ha realizado esa interpretación en base a otros testimonios de los que disponga. Someter a crítica una película histórica no debería ser una labor diferente a la labor que se realiza cuando se tiene una fuente escrita delante que, por otra parte, es la primera que puede tratarse de una completa falsificación. Si un historiador no despreciaría o se negaría a tener en consideración una fuente escrita solo porque su fiabilidad sea cuestionable, despreciar una película sólo porque sea algo muy posterior a los hechos y porque se considere de una completa invención constituye a mi modo de ver una postura sin ningún sentido.

El caso de Juan Sin Tierra que he analizado en este artículo demuestra cómo nos encontramos ante multitud de lecturas e interpretaciones del pasado. Es evidente que el monarca inglés no fue nunca un traidor de soterrada ideología comunista frente a un virtuoso hermano que aglutinaba todos los valores de la democracia. Si nos quedamos solo con lecturas superficiales como estas, podemos afirmar que el cine se lo inventa todo y no sirve para nuestro propósito, enrocándonos en interpretaciones enormemente subjetivas y parciales. Si vamos más allá y apreciamos cómo El león en invierno nos mostró a una persona con problemas psicológicos o cómo la versión de Disney fue más que certera al apuntar la constante e hiriente falta de cariño por parte de su madre, no podremos negar que el cine nos ha proporcionado diferentes puntos de vista merecedores de reflexión que no ha sido capaz de transmitirnos ningún documento. 


\section{FICHAS TÉCNICAS DE LAS PELÍCULAS COMENTADAS ${ }^{25}$}

King John (1899), dirigida por Walter PfefFer Dando, William K. L. Dickson y Herbert BEERBOHM TREe, Reino Unido, British Mutoscope \& Biograph Company. Robin de los bosques (Robin Hood, 1922), dirigida por Allan DwAN, Estados Unidos, United Artists.

Robin de los bosques (The adventures of Robin Hood, 1938), dirigida por Michael CuRTIZ y William KeIGHLEY, Estados Unidos, Warner Bros.

El temible Robin Hood (Rogues of Sherwood Forest, 1950), dirigida por Gordon Douglas, Estados Unidos, Columbia Pictures.

Ivanhoe (1952), dirigida por Richard THORPE, Estados Unidos, Metro Goldwyn Mayer.

El león en invierno (The lion in winter, 1968), dirigida por Anthony HARveY, Reino Unido y Estados Unidos, Haworth Productions.

Robin Hood (1973), dirigida por Wolfgang ReItherman y David Hand, Estados Unidos, Walt Disney Productions.

Robin y Marian (Robin and Marian, 1976), dirigida por Richard LesTER, Estados Unidos, Columbia Pictures y Rastar Pictures.

Robin Hood (2010), dirigida por Ridley ScotT, Reino Unido y Estados Unidos, Universal Pictures, Imagine Entertainment y Relativity Media.

\section{REFERENCIAS}

Aguilar, C. (2018): Guía del cine, Cátedra, Madrid.

Alarcão, M. (2001): Príncipe dos ladrões: Robin Hood na cultura inglesa (c. 1377-1837), Fundação CaLouste Gulbenkian, Lisboa.

Aliaga Almela, R. (2014): «Buenas y malas en el cine histórico: el personaje de Cleopatra», en M. Almela, Ma García y H. Guzmán (coords.), Malas, Universidad Nacional de Educación a Distancia, Madrid: 39-62.

Alonso, J.J.; Mastache, E.A.; Alonso, J. (2007): La Edad Media en el cine, T\&B Editores, Madrid.

Aurell, M. (2012): El Imperio Plantagenet: 1154-1214, Sílex, Madrid.

BARLOW, F. (1988): The feudal kingdom of England, 1042-1216, Longman, London \& New York.

Barrio Barrio, J.A. (2008): «La Edad Media en el cine de Estados Unidos», Imago temporis. Medium Aevum, 2: 426-452.

CAmpanile, D. (2019): «Ivanhoe al cinema e in televisione», en D. CAmpanile (ed.), Due secoli con Ivanhoe. Atti della giornata di studio: Pisa, 18 ottobre 2019, Pisa University Press, Pisa: 203-217.

Coma, J. (1995): Lo que el viento se llevó. Robín de los bosques, Dirigido por, Barcelona. De Isusi, J. (2004-2010): Los viajes de Juan Sin Tierra, Astiberri, Bilbao.

DisneY, W. (2007): Robin Hood, Everest, León.

Duby, G. (1988): El domingo de Bouvines: 24 de julio de 1214, Alianza, Madrid.

25 He incluido únicamente las fichas técnicas de las películas que he comentado por ser aquellas en las que aparece Juan Sin Tierra, extrayendo los datos de (AgulLAR, 2018) o de la web http:/ / imdb.com cuando se trata de datos o títulos que no aparecen en el libro de Carlos Aguilar. 
FatÁs Cabeza, G. (1999): «Espartaco, de S. Kubrick», en J. Uroz (ed.), Historia y cine, Universidad de Alicante, Alicante: 63-78.

Ferro, M. (1980): Cine e historia, Gustavo Gili, Barcelona.

FLORI, J. (2002): Ricardo Corazón de León: el rey cruzado, Edhasa, Barcelona.

García Marsilla, J.V. (2015): «Miradas a un tiempo oscuro. El cine y los estereotipos sobre la Edad Media», en M. Bolufer, J. Gomis y T. Hernández, (eds.), Historia y cine. La construcción del pasado a través de la ficción, Institución Fernando el Católico, Zaragoza: 135-158.

García Moreno, L.A. (1999): «Cleopatra: el film de Joseph L. Mankiewicz», en J. Uroz (ed.), Historia y cine, Universidad de Alicante, Alicante: 163-182.

Gillingham, J. (1999): Historians without hindsight: Coggeshall, Diceto and Howden on the early years of John's reign, en King John. New interpretations, The Boydell Press, Woodbridge.

Gillingham, J. (2012): Ricardo Corazón de León, Sílex, Madrid.

Given-Wilson, Ch. (1996): An illustrated history of late medieval England, Manchester University Press, Manchester.

Goytisolo, J. (1975): Juan sin tierra, Seix Barral, Barcelona.

Hamilton Ball, R. (1973): «Tree's King John film: an addendum», Shakespeare Quarterly, 24-4: 455-459.

Hernández Carrón, L.A.; SÁnchez Pozón, L. (1996): «Catálogo de mitos juveniles: de Ivanhoe a Elvis», Puertas a la lectura, 1: 7-9.

Hivergneaux, M. (2000): "Aliénor d'Aquitaine: le pouvoir d'une femme à la lumière de ses chartes (1152-1204)», en M. AurELl (ed.), La cour Plantagenêt: 1154-1204. Actes du colloque tenu à Thouars du 30 avril au 2 mai 1999, Centre d'Études Supérieures de la Civilisation Médiévale, Poitiers.

HoвsвAwм, E.J. (1976): Bandidos, Ariel, Barcelona.

Hueso Montón, A.L. (1996): «Géneros cinematográficos y literatura: un diálogo permanente», Moenia, 2: 285-292.

HuEso MonTón, A.L. (2001): «La biografía como modelo histórico-cinematográfico», Historia contemporánea, 22: 104-109.

Jotischку, A. (2008): The crusades: critical concepts in historical studies, Routledge, Londres.

KNIGH, S.T. (2003): Robin Hood: a mythic biography, Cornell University Press, Ithaca.

Le Goff, J. (2008): Una larga Edad Media, Paidós, Barcelona.

Marí COMPANy, F. (2015): Napoleón Bonaparte y el cine: una interpretación histórica, Tesis doctoral, Universitat de Barcelona, Barcelona.

Markale, J. (1999): La vida, la leyenda, la influencia de Leonor de Aquitania, dama de los trovadores y bardos bretones, Medievalia, Barcelona.

McLynn, F. (2007): Richard and John. Kings at war, Da Capo Press, Cambridge.

Millet, E. (2018): «¿Un rey pésimo? La fama de Juan I de Inglaterra», Historia y vida, 599: 52-59.

Monterde, J.E.; Selva, M.; SOlÀ, A. (2001): La representación cinematográfica de la historia, Akal, Madrid.

Montero DíEz, J. (2008): «La «realidad» histórica en el cine: el peso del presente», en $\mathrm{M}^{\mathrm{a}} \mathrm{G}$. Camarero, V. DE Cruz, y B. DE las Heras (coords.), I Congreso Internacional de Historia y Cine. 5, 6, 7 y 8 de septiembre de 2007, Universidad Carlos III, Madrid: 128-138.

Morris, M. (2015): King John. Treachery, tyranny and the road to Magna Carta, Hutchinson, Londres. 
Norgate, K. (1902): John Lackland, MacMillan and Co., London.

Pernoud, R. (2009): Leonor de Aquitania, Acantilado, Barcelona.

PotTer, L. (1998): Playing Robin Hood. The legend as performance in five centuries, University of Delaware Press y Associated University Press, Newark \& London.

PyLE, H. (2017): Las alegres aventuras de Robin Hood, Anaya, Madrid.

RodRíGUEZ LAJUSTICIA, F.S. (2020): «Un personaje histórico desde varias perspectivas: Ricardo Corazón de Léon en literatura, cine, crónicas y documentos», Santander. Estudios de Patrimonio, 3: 297-330.

Rosenstone, R. A. (1997): El pasado en imágenes. El desafío del cine a nuestra idea de la historia, Ariel, Barcelona.

Rosenstone, R.A. (2014): «La película histórica como campo, como modo de pensamiento (historiar) y un montón de malas jugadas que les hacemos a los muertos», en A. L. Hueso y M ${ }^{a}$ G. CAMARERo (coords.), Hacer historia con imágenes, Síntesis, Madrid: 19-30.

Scотт, W. (2013): Ivanhoe, Cátedra, Madrid.

SEEL, G.E. (2012): King John. An underrated king, Anthem Press, Londres y Nueva York.

SHAKESPEARE, W. (1968): El rey Ricardo II. La vida y la muerte del rey Juan, EspasaCalpe, Madrid.

Simeone, W.E. (1953): «The historic Robin Hood», The journal of American folklore, 262: 303-308.

SREBNICK, W. (1999): «Re-presenting History: Ivanhoe on the screen», Film $\mathcal{E}$ History: an interdisciplinary journal of film and television studies, 29: 46-54.

Stilton, G. (2012): Robin Hood, Destino, Barcelona.

Teja Casuso, R. (1999): «Historia y leyenda en la Roma del Quo vadis? (Mervyn Le Roy, 1951)», en J. Uroz (ed.), Historia y cine, Universidad de Alicante, Alicante: 89-100.

Von Tunzelmann, A. (2016): La loca, loca, loca historia del mundo según el cine, T\&B Editores, Madrid.

Warren, W.L. (1978): King John, University of California Press, Los Angeles. 